\title{
A dimensão moral das decisões administrativas e os limites da racionalidade limitada
}

\section{MARcos Luís ProcópIo}

\author{
Universidade do Estado de Mato Grosso (UNEMAT) / FACUldAde de CIÊNCIAS SOCIAIS AplicadAs (FACISA), SINOP - MT, BRASIL
}

\begin{abstract}
Resumo
Hoje, o estudo da decisão nas organizações apresenta uma considerável diversidade de abordagens epistemológicas, teórico-conceituais e metodológicas. Todavia, poucas ideias tiveram impacto tão profundo e duradouro no pensamento gerencial sobre as decisões quanto aquelas relacionadas à racionalidade limitada. Apresentada por Herbert Simon no final dos anos 1940, a racionalidade limitada supostamente contesta os pilares fundamentais da racionalidade plena, propondo um caminho mais "realista" para descrever como as escolhas são feitas pelos indivíduos nas organizações. A despeito dos avanços em relação ao modelo da racionalidade plena, será que a racionalidade limitada realmente representa uma mudança de paradigma na interpretação da decisão gerencial? Este ensaio teórico busca demonstrar que a teoria da racionalidade limitada não rompe substancialmente com a teoria da racionalidade plena, uma vez que ainda está longe de abordar os aspectos efetivamente relevantes da decisão gerencial, a saber, seus aspectos morais. O artigo também apresenta e discute elementos conceituais úteis para a edificação de uma teoria moral da racionalidade, a fim de demonstrar como uma verdadeira ruptura com a concepção de racionalidade de Simon pode ser articulada e quais seriam os avanços e as vantagens que tal ruptura traria à investigação dos processos decisórios nas organizações.
\end{abstract}

Palavras-chave: Racionalidade. Moralidade. Decisão gerencial. Herbert Simon. John Dewey.

\section{The moral dimension of managerial decisions and the limits of bounded rationality}

\begin{abstract}
The study of organizational decisions, nowadays, shows a great diversity of epistemological, theoretical-conceptual and methodological approaches. However, few ideas have had an impact as profound and lasting in management thinking about decisions, as those related to bounded rationality. Introduced by Herbert Simon in the late 1940s, bounded rationality supposedly denies the underpinnings of full rationality and proposes a more "realistic" way to describe how choices are made by individuals in organizations. In spite of its progress, when compared to the full rationality model, does bounded rationality really mean a paradigm shift in the interpretation of management decision? This theoretical essay aims to demonstrate that the bounded rationality model does not break with the orthodox model of full rationality, as it is still far from addressing the effectively relevant aspects of managerial decisions, namely, its moral aspects. This study also presents and discuss some conceptual elements which could be useful to build a moral theory of rationality in order to demonstrate how an actual disruption with Simon's rationality concept could be articulated and what would be the advances and benefits that such disruption could bring to the investigation of the decision-making processes in organizations.
\end{abstract}

Keywords: Rationality. Morality. Managerial decision. Herbert Simon. John Dewey.

\section{La dimensión moral de las decisiones administrativas y los límites de la racionalidad limitada}

\section{Resumen}

El estudio de la decisión en las organizaciones presenta actualmente una considerable diversidad de abordajes epistemológicos, teóricoconceptuales y metodológicos. No obstante, pocas ideas tuvieron un impacto tan profundo y duradero en el pensamiento gerencial sobre las decisiones como las relacionadas a la racionalidad limitada. Presentada por Herbert Simon a fines de los años 1940, la racionalidad limitada supuestamente contesta los pilares fundamentales de la racionalidad plena, proponiendo un camino más 'realista' para la descripción de cómo los individuos toman las decisiones en las organizaciones. ¿A pesar de los avances en relación al modelo de la racionalidad plena, la racionalidad limitada representa realmente un cambio de paradigma en la interpretación de la decisión gerencial? El presente ensayo teórico busca demostrar que la teoría de la racionalidad limitada no rompe sustancialmente con la teoría de la racionalidad plena, puesto que aquella todavía está lejos de abordar los aspectos efectivamente relevantes de la decisión gerencial, a saber, sus aspectos morales. El artículo también presenta y discute algunos elementos conceptuales útiles para la construcción de una teoría moral de la racionalidad, a los efectos de demostrar cómo puede articularse una verdadera ruptura con la concepción de racionalidad de Simon y cuáles serían los avances y ventajas que tal ruptura aportaría a la investigación de los procesos decisorios en las organizaciones.

Palabras clave: Racionalidad. Moralidad. Decisión gerencial. Herbert Simon. John Dewey. 


\section{INTRODUÇÃO}

Ao lado do poder, da cooperação e da motivação, a decisão é um tema recorrente e fundamental nos Estudos Organizacionais e na Administração. Embora o estudo da decisão nas organizações apresente, hoje, uma considerável diversidade de abordagens epistemológicas, teórico-conceituais e metodológicas (SCHWARTZ, 2016; ELM e RADIN, 2012; WOICESHYN, 2011; PROVIS, 2010; MOTTA e VASCONCELOS, 2004; MILLER, HICKSON e WILSON, 2004; SCHOEMAKER, 1993; ETZIONI, 1988), poucas ideias tiveram um impacto tão profundo e duradouro no pensamento gerencial sobre as decisões quanto aquelas relacionadas à racionalidade limitada.

Apresentada por Herbert Simon no final dos anos 1940, a racionalidade limitada supostamente contesta os pilares fundamentais da racionalidade plena dos agentes decisores, oriundos do pensamento econômico neoclássico, propondo um caminho mais "realista" para descrição de como as escolhas são feitas nas organizações (SIMON, 1979; MILLER, HICKSON e WILSON, 2004; MOTTA e VASCONCELOS, 2004). A racionalidade limitada tem servido como fonte de inspiração para diversas outras elaborações teóricas cujo propósito é desnudar a tomada de decisão nas organizações, como as teorias incrementalistas, intuitivas e heurísticas (MOTTA e VASCONCELOS, 2004; SIMON, 1989; ETZIONI, 1988). Não obstante, a racionalidade limitada tem exercido influência nos mais diversos campos do conhecimento além da Administração e da Economia (BALESTRIN, 2002). Portanto, a teoria da racionalidade limitada goza de grande prestígio acadêmico e ainda é considerada atual quando se trata do processo decisório nas organizações.

A despeito de seus avanços em relação ao modelo da racionalidade plena, será que a racionalidade limitada realmente representa uma mudança de paradigma na interpretação da decisão gerencial?

Este ensaio teórico tem por objetivo demonstrar, a partir das contribuições críticas de Guerreiro Ramos (1989), além de outros autores, que, a despeito do avanço que o conceito de racionalidade limitada trouxe, em relação ao modelo ortodoxo da racionalidade plena, ao estudo do comportamento administrativo, ele ainda está longe de abordar os aspectos efetivamente relevantes da decisão gerencial, a saber, seus aspectos morais.

Alberto Guerreiro Ramos se notabilizou, dentre outras coisas, por seus estudos aprofundados e críticos acerca do conceito de racionalidade na Administração e nos Estudos Organizacionais. Suas contribuições em A nova ciência das organizações, 1989, são fundamentais tanto para a crítica ao conceito de racionalidade de Simon quanto para a posterior edificação de uma teoria moral da racionalidade, efetivamente "substantiva". Assim, são incorporadas como ideias fundamentais neste ensaio teórico suas críticas ao conceito hegemônico de racionalidade instrumental, como seu caráter mecanomórfico e seu esvaziamento ético, bem como as discussões acerca de duas "síndromes comportamentalistas", produzidas pelo uso indiscriminado dessa modalidade de racionalidade, identificadas pelo autor como "fluidez da individualidade" e "formalismo". Indiretamente, são trazidas a este debate as críticas de Guerreiro Ramos (1989) acerca da falsa dicotomia entre "fato" e "valor", existente nas Ciências Sociais ortodoxas, bem como suas críticas à epistemologia positivista e operacionalista que domina a ortodoxia dos Estudos Organizacionais e da Ciência da Administração.

Ao todo, 7 limitações da concepção de racionalidade limitada são apontadas e discutidas neste ensaio: 1) o conceito de racionalidade limitada está circunscrito ao conceito de racionalidade plena, 2) o conceito de racionalidade limitada traz uma visão mecanomórfica da racionalidade, 3) a racionalidade limitada pressupõe uma única dimensão de utilidade, 4) a teoria da racionalidade limitada descreve, mas não explica, a decisão nas organizações, 5) a teoria da racionalidade limitada oculta a dimensão ética das escolhas humanas, 6) a teoria da racionalidade limitada não capta a verdadeira essência humana e social da deliberação, e 7) a teoria da racionalidade limitada descreve a decisão a partir da negação da racionalidade.

Ademais, este ensaio teórico também tem por objetivo, em um segundo momento, indicar e discutir elementos conceituais para a edificação de uma teoria moral da racionalidade capaz de suprir as principais lacunas da teoria da racionalidade limitada de Simon. Para tanto, são trazidas ao debate algumas ideias seminais discutidas pelo filósofo pragmatista John Dewey, como padrões morais, valoração e deliberação moral.

O pragmatismo de Dewey se volta aos desdobramentos concretos da conduta moral em várias esferas da vida social cotidiana e, por isso, não se limita a uma reflexão ética meramente especulativa. Ademais, Dewey fornece, no conjunto de sua obra, todos os subsídios lógicos, ontológicos, epistemológicos, teóricos e conceituais necessários para o debate da moralidade na decisão gerencial. Com efeito, "é a Dewey que é preciso atribuir o crédito de haver formulado uma concepção inteiramente desenvolvida de ética como ciência" (PUTNAM, 2003, p. 376). 
Em termos de estrutura, este artigo se divide em 3 seções, além desta introdução e das considerações finais. Na primeira seção, almeja-se demonstrar que a crítica de Simon contra o modelo ortodoxo do homem econômico ficou restrita aos elementos informacionais objetivos e computacionais subjetivos da racionalidade plena. Mais especificamente, ficou restrita à onisciência do agente decisor - necessária para que ele possa dispor de todas as informações sobre tudo aquilo que interfere na determinação da melhor escolha - e à sua onipotência - necessária para que ele seja capaz de analisar e comparar, a tempo de fazer a melhor escolha, todos os dados e fatos relacionados às opções de ação e suas consequências. Além disso, os demais pressupostos epistemológicos e teóricos do modelo da racionalidade plena permaneceram inalterados na crítica de Simon, especialmente aqueles que impõem a separação entre fatos e valores.

Embora Simon tenha apresentado uma teoria da racionalidade ainda filiada ao pensamento neoclássico, que ele mesmo se propôs a criticar, alguns de seus esforços para a compreensão do "comportamento administrativo" e da "razão nas coisas humanas" contribuíram para que fosse possível avançar na direção de uma teoria realmente nova da racionalidade. As contribuições de Simon para uma teoria moral da racionalidade e da decisão nas organizações são apontadas e discutidas na segunda seção deste ensaio teórico.

Na terceira seção, que antecede as considerações finais, propõe-se aprofundar a discussão - realizada com base em autores seminais como John Dewey - que debate a moralidade na decisão de modo geral - Amitai Etzioni - que debate a moralidade na decisão administrativa mais especificamente - e Frederick Bird e James Waters - que se propuseram a investigar empiricamente a decisão moralmente orientada junto a diversos gestores - de alguns elementos conceituais úteis para a edificação de uma teoria moral da racionalidade, a fim de demonstrar como uma verdadeira ruptura com a concepção de racionalidade de Simon pode ser articulada.

Nas considerações finais são apontados e discutidos os principais avanços e vantagens que a (re)incorporação da dimensão ética na teoria da racionalidade pode trazer à investigação das decisões nas organizações.

\section{RACIONALIDADE PLENA, RACIONALIDADE LIMITADA E VISÃO MECANOMÓRFICA DO AGENTE DECISOR}

Antes de Simon propor a teoria da racionalidade limitada, no final dos anos 1940, o modelo de agente decisor que ocupava espaço no pensamento administrativo era o do "homem econômico", detentor de uma racionalidade plena (ETZIONI, 1988). Segundo Miller, Hickson e Wilson (2004, p. 284), esse modelo, que incorpora em seu âmago os pressupostos econômicos neoclássicos, apoia-se nas "suposições de que os indivíduos normalmente agem como empreendedores maximizadores, que tomam decisões num processo sequencial e linear"1. De acordo com Simon (1979, p. 70), nesse modelo de racionalidade plena,

[...] a tarefa de decidir compreende três etapas, a saber: a) o relacionamento de todas as possíveis estratégias, b) a determinação de todas as consequências que acompanham cada uma dessas estratégias, e c) a avaliação comparativa desses grupos de consequências.

Como complementa Simon (1979, p. 70, grifo do autor), na mesma passagem, "aqui, a palavra todas é usada deliberadamente". Seu significado sugere, de fato, onisciência e onipotência por parte do agente decisor.

Miller, Hickson e Wilson (2004, p. 284) enfatizam que "durante todo o processo é mantida com mão de ferro a filosofia de maximizar as recompensas e minimizar os custos para todos os envolvidos". O homem econômico é, então, aquele que, consciente de todos os dados e fatos implicados na sua decisão, é capaz de encontrar, em tempo hábil, o curso de ação que trará, do modo mais eficiente possível, os resultados por ele esperados. O homem econômico sempre faz, portanto, escolhas ótimas (SIMON, 1979).

Todavia, de acordo com Simon (1979), os limites da racionalidade do homem econômico são encontrados justamente na incapacidade do ser humano de dispor, em tempo hábil, de todos os dados ligados à escolha, de analisar todas as alternativas possíveis de ação e de comparar suas consequências a fim de escolher a opção ótima. Como explica o autor, a limitação da racionalidade reside no fato de que, "ao tomar decisões administrativas, é preciso escolher continuamente premissas [...]

${ }^{1} \mathrm{Na}$ literatura especializada, a racionalidade plena possui diversos sinônimos: racionalidade objetiva, pura, perfeita, olímpica ou ainda "utilidade subjetiva esperada (USE)", sendo que esses dois últimos termos foram empregados por Simon (1989) para designar a mesma concepção plena de racionalidade. 
cuja veracidade ou falsidade não se conhece claramente e nem se pode determinar com segurança à luz das informações e do tempo disponível" (SIMON, 1979, p. 53). Os objetivos perseguidos pelos agentes decisores podem ser ambíguos, imprecisos ou mesmo podem se alterar no decurso do processo decisório (MILLER, HICKSON e WILSON, 2004; ETZIONI, 1988). Além disso, o processo racional pode ser drasticamente dificultado, na medida em que aumenta a complexidade do contexto macro e micro-organizacional no qual a decisão ocorre. Isso porque, quanto mais complexo for o ambiente da escolha, mais variáveis estarão envolvidas no cálculo das alternativas de ação (ETZIONI, 1988). Portanto, mais tempo e recursos o agente decisor deverá despender para mapeá-las e analisá-las a fim de determinar a escolha ótima (MILLER, HICKSON e WILSON, 2004). Percebe-se, então, que o modelo da racionalidade plena se trata de uma "ficção" em termos daquilo que os seres humanos são capazes de fazer (MOTTA e VASCONCELOS, 2004). "É impossível, evidentemente, que o indivíduo conheça todas as alternativas de que dispõe ou todas as suas consequências" (SIMON, 1979, p. 70, grifo do autor). Como resumem Miller, Hickson e Wilson (2004, p. 284, grifo do autor),

Simon argumenta que, restringidos tanto pela complexidade das organizações modernas como por suas próprias capacidades cognitivas limitadas, os tomadores de decisão são incapazes de operar em condições de racionalidade perfeita. A questão sobre a qual se decide provavelmente não é clara ou pode ser objeto de diversas interpretações; informações sobre alternativas podem não estar disponíveis, ser incompletas ou mal representadas; e os critérios pelos quais soluções potenciais são avaliadas são geralmente incertos ou não estão de acordo com as próprias alternativas. Além disso, o tempo e a energia disponíveis para os tomadores de decisão buscarem maximização de resultados são limitados e finitos. A procura por melhores escolhas pode simplesmente levar um tempo demasiadamente longo. A consequência dessas restrições é que o resultado será provavelmente "satisfatório" (satisficing) e não ótimo [...].

A constatação da impossibilidade de existência da racionalidade plena fez então com que Simon (1979) se propusesse a reformar o conceito de homem econômico, buscando uma definição de agente decisor mais próxima da realidade que caracteriza a decisão concreta nas organizações. Assim,

[...] enquanto o homem econômico maximiza seus esforços, selecionando a melhor alternativa entre as que se lhe apresentam, seu primo, a quem chamaremos de homem administrativo, contemporiza, isto é, busca um curso de ação satisfatório ou razoavelmente bom (SIMON, 1979, p. XXIV).

Por isso, complementa Simon (1979, p. 6), para o homem administrativo, "a alternativa finalmente escolhida jamais permite a realização completa ou perfeita dos objetivos visados, representando apenas a melhor solução encontrada naquelas circunstâncias".

De acordo com Motta e Vasconcelos (2004, p. 106), o ser humano é concebido, nessa "nova" teoria do homem administrativo, de modo mais modesto e realista: não é considerado o ser onisciente e plenamente racional do modelo econômico clássico.

Embora o modelo do homem administrativo seja melhor adequado à realidade dos agentes que efetivamente tomam decisões nas organizações e, portanto, seja capaz de melhor descrever o comportamento administrativo do que o modelo do homem econômico, ele ainda não captura a verdadeira essência humana e social da decisão gerencial. Isso se deve, ao menos parcialmente, ao fato do conceito de racionalidade limitada de Simon ainda estar preso ao conceito de racionalidade plena, por ele criticado.

\section{O CONCEITO DE RACIONALIDADE LIMITADA ESTÁ CIRCUNSCRITO AO CONCEITO DE RACIONALIDADE PLENA}

Diversos autores apontaram que, a despeito de todas as críticas dirigidas à racionalidade plena, o modelo da racionalidade limitada de Simon ainda pertence ao paradigma do homem econômico maximizador, cuja racionalidade é plena.

De acordo com Miller, Hickson e Wilson (2004, p. 297), no modelo da racionalidade limitada de Simon, "os indivíduos esforçam-se por decidir racionalmente, mas são impedidos pela falta de um conhecimento perfeito, em razão dos limites da própria cognição humana. Todavia, permanece a intenção da coerência". Para Guerreiro Ramos (1989), embora o homem real não possa ser visto como um ser plenamente racional, devido às suas limitadas capacidades, o modelo de racionalidade proposto por Simon ainda se baseia na busca pelo conhecimento total das opções e das consequências de ação. Baseando-se em James March, Reed (1998, p. 68), por sua vez, afirma que 
[...] ainda que o conceito de Simon de "racionalidade limitada" e sua teoria de "comportamento administrativo" se baseiem em uma crítica mordaz ao racionalismo e formalismo excessivos presentes na teoria organizacional e gerencial, suas ideias também fundamentam-se em uma abordagem que entende a escolha racional, entre opções claramente delineadas, como base da ação social.

Do mesmo modo, para Carvalho e Vieira (2003, p. 22),

[...] o modelo de comportamento de Simon enfrenta a concepção racionalista da ação [...] No entanto, este modelo mantém que as ações são resultado de um cálculo racional, ou seja, estão inda subordinadas à razão, ainda que de forma limitada [...].

Além dos apontamentos desses autores, outras evidências que demonstram que a racionalidade limitada de Simon ainda pertence ao domínio da racionalidade perfeita, por ele criticada, podem ser encontradas na justificativa dada pelo próprio Simon (1979) para a existência da Ciência Administrativa e das teorias das organizações e da administração.

Para Simon (1979, p. XXIII, grifo do autor), "a teoria administrativa é, na sua essência, a teoria da racionalidade intencional e limitada do comportamento dos seres humanos que contemporizam porque não possuem meios para maximizar". Ela se preocupa "com os problemas de como se deve planejar e administrar uma organização, de modo a realizar sua tarefa da maneira mais eficiente" (SIMON, 1979, p. 40). Por isso, "a teoria administrativa diz respeito ao controle de aspectos não racionais" das escolhas (SIMON, 1979, p. 256) e "deve preocupar-se com os limites da racionalidade" (SIMON, 1979, p. 253), pois "é precisamente na área em que o comportamento humano é intencional, embora limitadamente racional, que se encontram as maiores possibilidades para o desenvolvimento de uma autêntica teoria de organização e administração" (SIMON, 1979, p. XXII, grifo do autor).

Vê-se então que, para Simon (1979), a Ciência Administrativa deve ocupar-se com a busca da racionalidade perfeita, embora inatingível na prática, oferecendo aos gestores modos de amenizar as indesejáveis limitações da racionalidade dos agentes organizacionais. Afinal, "a teoria administrativa seria estéril se a racionalidade humana não fosse limitada" (SIMON, 1979, p. 252).

Por fim, não é apenas ao justificar a necessidade e a existência de uma teoria da administração que Simon revela a filiação de sua concepção de racionalidade limitada à concepção neoclássica de racionalidade plena que ele mesmo busca criticar. Tal filiação também se torna bastante evidente quando Simon associa as ideias de otimização e eficiência à ideia de racionalidade.

Para Simon a eficiência é a pedra de toque da deliberação racional, seja ela limitada ou não. Sem embargo, Simon (1979, p. 14) entende o critério da eficiência como o "princípio inerente a todo comportamento racional"2. De acordo com Simon (1979, p. 67, grifo do autor), "a eficiência, no sentido de obtenção de resultados máximos com meios limitados, deve constituir um critério orientador das decisões administrativas". A "maximização constitui a finalidade da atividade administrativa e [...] a teoria administrativa deve exprimir as condições em que essa maximização ocorre" (SIMON, 1979, p. 40). Contudo, "não se quer dizer com isso que o critério da eficiência predomina sempre nas decisões dos administradores, mas que deveria predominar se eles fossem racionais" (SIMON, 1979, p. 190). Afinal, a plena eficiência, vista como maximização de resultados, somente poderia ser conquistada se a racionalidade dos agentes decisores não fosse limitada.

Ao associar a racionalidade dos agentes decisores à ideia de eficiência, entendendo esta como a busca pela maximização de resultados, Simon é obrigado a reconhecer a proximidade de sua concepção de racionalidade da concepção de racionalidade plena, oriunda da economia neoclássica. Em suas próprias palavras, "o critério da eficiência, da maneira como é aplicado às decisões administrativas, é, conforme pode ver-se, quase idêntico ao conceito de maximização da utilidade na teoria econômica" (SIMON, 1979, p. 190).

Se, como ora demonstrado, a racionalidade limitada ainda pertence ao domínio da racionalidade perfeita, caracterizando-se, acima de tudo, como uma racionalidade perfeita que não pode ser perfeita, então, algumas das críticas às quais a teoria da racionalidade perfeita está sujeita também recaem sobre a teoria da racionalidade limitada.

\footnotetext{
2"No sentido mais amplo, ser eficiente significa simplesmente tomar o caminho mais curto e os meios mais econômicos para alcançar determinados objetivos" (SIMON, 1979, p. 14). Significa, portanto, maximizar resultados.
} 


\section{O CONCEITO DE RACIONALIDADE LIMITADA TRAZ UMA VISÃO MECANOMÓRFICA DA RACIONALIDADE}

Guerreiro Ramos (1989) demonstra como Simon subverteu o conceito de racionalidade, amplamente discutido na literatura ocidental, de Aristóteles a Max Weber, retirando dos agentes decisores, em sua concepção, toda e qualquer habilidade crítica e autônoma de avaliação e escolha. No espaço anteriormente ocupado por essa habilidade crítica e autônoma, que conferia aos agentes decisores o status de sujeitos racionais, capazes de avaliar o valor qualitativo das coisas e ações, Simon coloca apenas um parâmetro de avaliação, a eficiência, vista como maximização de utilidades.

Como concebida por Simon, a racionalidade humana passa a figurar, então, como uma habilidade de cálculo meramente instrumental, não tendo nada a dizer sobre a natureza qualitativa dos meios e fins das ações humanas. De modo figurado, o agente decisor passa a se comportar como um "computador" que, mediante a entrada de dados factuais precisos e completos, que Simon $(1979,1989)$ chama de "premissas decisórias", trabalha, dentro de suas limitações analíticas, para encontrar a alternativa ótima de ação, ou seja, aquela que garanta a maior eficiência. Como explica o próprio Simon (1989, p. 16), "a razão funciona [...] só depois de ter recebido um conjunto adequando de informações iniciais". Trata-se, aqui, da manifestação prática do truísmo lógico, admitido pelo autor, segundo o qual "não há conclusões sem premissas". Então, continua Simon (1989), quando a razão é aplicada à escolha de alternativas de ação, devem estar presentes pelo menos duas premissas de conteúdo factual: uma premissa contendo os dados sobre os resultados que serão alcançados por meio da ação e outra contendo as condições objetivas dentro das quais a ação decorrerá. Dito de outro modo, tratam-se, respectivamente, dos fins e dos meios disponíveis de ação, tais como concebidos factualmente.

Todavia, para Simon, tais premissas não dizem respeito apenas aos meios e fins previamente selecionados pelo agente decisor. Ao contrário, Simon $(1979,1989)$ insiste no fato de que todos os possíveis efeitos das escolhas devem ser considerados pelo agente decisor ao se buscar racionalmente a alternativa de ação ótima, e que não considerá-los implica "uma falácia estritamente associada à aplicação do critério da eficiência" (SIMON, 1979, p. 194). É, então, na comparação exaustiva desses dois conjuntos de premissas, satisfeita sempre a partir da determinação dos meios mais eficientes para se chegar ao fim pretendido, em face das demais condições restritivas da ação, que reside a racionalidade, segundo Simon. Assim, "aqueles que se inclinam pela matemática verão nessa estrutura um conjunto de equações, exatamente iguais às chamadas funções de produção do economista" (SIMON, 1979, p. 197, grifo do autor). "Veremos, então, que o problema das decisões administrativas pode ser convertido num problema de campo da teoria da produção, e que os conceitos e teoremas desenvolvidos na teoria econômica têm ampla aplicação nas decisões administrativas" (SIMON, 1979, p. 191).

Uma ação racional é, então, aquela que atinge a meta com o menor gasto de recursos possível, e nada mais. Para Simon (1979, p. 197), "o problema da eficiência consiste em descobrir o máximo de uma função de produção". Por certo, Simon "não hesitou em escrever que a gestão científica não precisa ter uma filosofia diferente da pesquisa operacional" (CHANLAT, 1999, p. 38).

Vê-se, então, que Simon reduz o agente decisor a um ser que calcula matematicamente, embora o alcance e a precisão dos seus cálculos sejam limitados. Não cabe a esse agente refletir qualitativamente sobre os meios ou fins das decisões em si, já que o cálculo utilitário de consequências não os ajuda nesse intento. Da mesma forma, não cabe a esse agente refletir sobre o que deve ser feito, por que deve ser feito e para quem deve ser feito, mas apenas encontrar o caminho mais eficiente para fazê-lo. Assim, argumenta Guerreiro Ramos (1989, p. 30), "no momento em que o ser humano é reduzido a uma criatura que calcula, é para ele impossível distinguir entre o vício e a virtude".

Como admite Simon (1989, p. 15), “o princípio de que 'não há conclusões sem premissas' exclui definitivamente as informações de caráter normativo". Ou seja, "o corolário de que 'não há conclusões sem premissas' é 'não se pode concluir o tem de ser a partir do ser" (SIMON, 1989, p. 15, grifo do autor). A partir daí, Simon (1989, p. 15) constata que, "pelo fato de a razão nos poder fornecer uma ajuda preciosa para encontrarmos os meios de atingirmos os nossos fins, pouco ou nada nos diz sobre os próprios fins". Segundo Guerreiro Ramos (1989, p. 121-122, grifo do autor),

[...] para Simon, a racionalidade na conduta ou nas decisões humanas nunca é uma questão de conteúdo qualitativo intrínseco, mas antes questão de ser ou não instrumental para a consecução de objetivos ou fins. Em consequência, questões como a do que é bom, no homem ou na sociedade, não tem lugar na área do debate racional. O homem racional não se preocupa com a ética dos fins per se. É um ser que calcula, decidido apenas a encontrar, com precisão, meios adequados para atingir metas, indiferente ao respectivo conteúdo de valor [ético]. 
Esvaziado de sua faculdade ética e de seu senso crítico e autônomo de avaliação, não resta mais nada ao ser humano a não ser se comportar, então, como uma máquina. A razão perde todo o conteúdo propriamente humano e social que, de acordo com Guerreiro Ramos (1989), acompanhou-a na visão de inúmeros pensadores ocidentais, de Aristóteles a Max Weber. Não obstante, impossibilitado de avaliar qualitativamente os meios e fins envolvidos em suas escolhas, o indivíduo passa a se comportar de modo fluido e meramente formal.

Guerreiro Ramos (1989) explica que a fluidez da individualidade e o formalismo são manifestações de uma "síndrome comportamentalista", caracterizada justamente pela eliminação da faculdade ética e do senso crítico e autônomo de avaliação das pessoas. Sujeita a essa síndrome, a ação humana deixa de ser propriamente humana e passa a ser um comportamento "desprovido de conteúdo ético de validade geral. É um tipo de conduta mecanomórfica, ditada por imperativos exteriores [...] inclui-se, completamente, num mundo determinado apenas por causas eficientes" (GUERREIRO RAMOS, 1989, p. 51).

A síndrome comportamentalista é, segundo Guerreiro Ramos (1989), o produto de uma supersocialização do ser humano, na qual os indivíduos assumem, de modo acrítico, o princípio da eficiência como único guia para seu comportamento. Na sociedade moderna, argumenta Guerreiro Ramos (1989, p. 111), "o ambiente social, como um todo, tornou-se, ele próprio, um ambiente mecanomórfico e, pela interiorização de suas normas e exigências, o indivíduo é induzido a se transformar, a si mesmo, num sistema mecanomórfico". Assim, "na verdade, o homem moderno é uma fluida criatura calculista que se comporta, essencialmente, de acordo com regras objetivas de conveniência" (GUERREIRO RAMOS, 1989, p. 54). Do mesmo modo, o formalismo se caracteriza, de acordo com Guerreiro Ramos (1989), como o comportamento no qual a forma, e não a substância, é o que importa ao indivíduo. Assim, explica o autor, "a observância das regras substitui a preocupação pelos padrões éticos substantivos" (GUERREIRO RAMOS, 1989, p. 59) e "a correção da conduta humana está em sua mera forma, não em seu conteúdo intrínseco" (GUERREIRO RAMOS, 1989, p. 62).

\section{A RACIONALIDADE LIMITADA PRESSUPÕE UMA ÚNICA DIMENSÃO DE UTILIDADE}

A concepção neoclássica de racionalidade está baseada na busca individual pela maximização da utilidade (MILLER, HICKSON e WILSON, 2004; ETZIONI, 1988). Entretanto, afinal, o que é "utilidade"?

Ao questionar a natureza do conceito de "utilidade", presente no paradigma neoclássico da racionalidade, Etzioni (1988) chega à conclusão de que se trata de um conceito vazio, meramente formal, onde nem o prazer nem o consumo são assumidos substantivamente como conteúdos. Trata-se, segundo Etzioni (1988), simplesmente de uma variável " $X$ ", que pode se referir a qualquer coisa, boa ou ruim, cuja comparação das quantidades permite ranquear preferências.

Em sua crítica a esse conceito de utilidade, Etzioni (1988) ressalta justamente a falta de substantividade e o excesso de abstração que, segundo esse autor, embora favoreçam a realização do cálculo utilitário de consequências, impedem uma análise qualitativa dos fenômenos em apreço. Assim, Etzioni (1988, p. 30) argumenta que, "diferentemente da matemática, a ciência requer conceitos substantivos. Nos cálculos matemáticos é possível usar denominadores comuns, formais e sem conteúdo, porque os elementos que estão sendo convertidos são, eles próprios, abstratos".

Etzioni (1988) expõe que existem duas maneiras de lidar, dentro do paradigma neoclássico da racionalidade, com a diversidade e complexidade das "utilidades" que são consideradas pelo agente decisor, muitas vezes em conflito, no processo de avaliação e escolha. O primeiro caminho, mais usual, consiste em assumir uma única perspectiva de utilidade como o "Iucro" ou a "renda" que, a princípio, seria supostamente abrangente o bastante para descrever o comportamento do agente decisor. Assim, diante de diversas opções de emprego, o candidato simplesmente escolheria aquele que maximiza sua renda. Aqui, analisa Etzioni (1988), o erro consiste na redução do comportamento complexo da decisão a um único critério arbitrário e universal de julgamento e escolha. Trata-se de uma monoutilidade absoluta.

A segunda solução ortodoxa, de acordo com Etzioni (1988), consiste em reconhecer a existência de muitas dimensões de utilidade, ao mesmo tempo que se insiste no argumento de que todas elas devem ser quantitativamente operacionalizadas dentro de um conceito único de utilidade, uma espécie de "suprautilidade". Aqui, analisa Etzioni (1988), o erro consiste na redução de diferentes dimensões qualitativas envolvidas no processo de julgamento e escolha a uma única dimensão quantitativa e empobrecida de descrição desse processo. Então, utilizando o mesmo exemplo do candidato ao emprego, a melhor escolha de trabalho seria aquela que maximizasse a renda e minimiza-se, ao mesmo tempo, fatores negativos como a frequência de 
viagens que acarretam distância da família. O fato da "renda" e da "distância da família" serem variáveis qualitativamente diferentes, percebidas e julgadas de modo igualmente diferente pelo candidato ao emprego, pouco importa nesta concepção de suprautilidade, uma vez que ambas devem ser correlacionadas para que a escolha ótima possa ser encontrada. Faz-se necessário, então, que a distância da família tenha um "preço" que possa ser comparado com a renda. Trata-se, aqui, de uma monoutilidade composta, porém, igualmente reducionista.

Esta última concepção de monoutilidade é a que Simon (1979, p. 14) adota ao entender o critério da eficiência como o "princípio inerente a todo comportamento racional" e ao assumir que todos os meios e fins empiricamente envolvidos nas escolhas, previstos ou imprevistos pelo agente decisor, devem ser considerados na decisão administrativa que se pretende racional. Considerar todos os meios e todos os fins implica, segundo Simon (1979), ser capaz de colocar, na mesma "balança econômica", os mais diversos elementos envolvidos nos processos de escolha. Afinal, "quando se toma uma decisão de acordo com o critério da eficiência é necessário conhecer empiricamente os resultados que estão associados com cada alternativa possível" (SIMON, 1979, p. 196). Voltando ao exemplo do candidato ao emprego, está claro que tanto a renda quanto a quantidade de vezes que é necessário ficar distante da família em determinado período de tempo são variáveis que podem ser empiricamente testadas. Todavia, será que ambas podem ser livremente comparadas sob um único critério de julgamento?

Para Simon (1979), considerar os elementos empíricos envolvidos nas escolhas significa simplesmente considerar os elementos factuais e objetivos envolvidos nas escolhas, e nada mais. Por serem plenamente "objetivos", ou seja, por estarem "factualmente" implicados nas opções de ação de forma inconteste, independentemente da vontade de qualquer agente social, tais elementos passam a dispor da única condição necessária ao julgamento e à escolha racional de acordo com Simon (1979): a neutralidade moral. Não é por acaso que, para Simon (1979, p. 14), "o critério da eficiência é completamente neutro quanto às metas a serem alcançadas".

Dentro da proposta teórica e epistemológica de Simon (1979), o problema da comparação de diferentes utilidades seria supostamente sanado se todas as variáveis envolvidas nas escolhas fossem, então, neutras. Sendo neutras, elas se tornariam variáveis "objetivas", estariam livres do "dever ser" e, assim, poderiam ser diretamente comparadas umas às outras. Todavia, essa abordagem apresenta algumas limitações.

No campo da Administração, o próprio Simon (1979) reconheceu explicitamente os riscos envolvidos no emprego indiscriminado da neutralidade no processo decisório gerencial. Em suas palavras,

[...] considerar como neutra a própria atividade administrativa constitui uma abstração permitida dentro de amplos limites, mas que, se levada a extremos, termina por ignorar valores humanos de suma importância. Esses valores podem abranger a remuneração e as condições de trabalho (aqui usados num sentido amplo) dos membros do grupo que realizam a atividade (SIMON, 1979, p. 193).

Assim, "o ritmo de trabalho dos empregados não pode ser considerado como um elemento neutro, pois poderíamos ser levados a concluir que sua aceleração seria sempre desejável" (SIMON, 1979, p. 193, grifo do autor). Do mesmo modo, continua o autor, "as políticas salariais, de promoção, e assim por diante, precisam ser consideradas não apenas como aliciantes e com vistas à eficiência dos resultados, mas também do ponto de vista da justiça distributiva para os membros do grupo" (SIMON, 1979, p. 194).

Com efeito, o "ritmo de trabalho" não é uma variável decisória que pode ser livremente reduzida à eficiência para efeito de decisão gerencial, a despeito de sua indubitável manifestação empírica. O mesmo vale para "salário" e "equidade" ou "justiça distributiva" que, todavia, podem ser medidos e comparados por unidades monetárias. Entretanto, existem outras dimensões não quantitativas subjacentes a essas variáveis que se estendem para além de sua mensuração quantitativa. Dito de outro modo, essas variáveis, inegavelmente quantificáveis, pertencem a diferentes dimensões qualitativas de valor que somente podem ser comparadas dentro de uma mesma dimensão quantitativa, como a dimensão da eficiência, sob pena de perda de seu conteúdo e riqueza próprios.

Vê-se que, em ambos os exemplos, a correlação matemática entre as variáveis envolvidas nas escolhas gerenciais somente pode ser conseguida artificialmente, sob pena da perda do sentido e da representatividade própria que cada uma delas tem para o agente decisor. Como observa Etzioni (1988), o que é considerado "justo" é certamente um problema de julgamento moral e não produto da determinação econômica. Quem julga algo como "justo" ou "injusto" o faz mediante uma concepção eminentemente qualitativa de justiça e não meramente quantitativa. Por isso, a justiça não pode ser reduzida a um valor 
neutro ou formal. Inversamente, como seria possível saber, por exemplo, depois de determinadas as medidas ideais de "salário" e "produtividade" em uma decisão maximizadora da eficiência, se a administração de uma empresa está tratando de modo "justo" seus funcionários?

Daí segue que nem todos os elementos condicionantes da decisão gerencial podem ser satisfatoriamente submetidos a um mesmo critério quantitativo de suprautilidade para fins de cálculo da escolha ótima. Por isso, decidir não se trata de reduzir, como propõe Simon (1979), todos os meios e consequências das opções de escolha, previstos ou imprevistos, à mesma dimensão quantitativa de utilidade a fim de se encontrar o caminho que maximize a eficiência na realização de metas. Ao contrário, trata-se de reconhecer, como fez Etzioni (1988), que as escolhas humanas contemplam diversas dimensões qualitativamente diferentes de "utilidade" que não podem ser reduzidas em uma mesma "equação", embora inda sejam amplamente consideradas pelos agentes decisores em suas escolhas, muitas vezes envoltas em conflitos e dilemas.

Assim, embora Simon (1979) tenha se proposto a criticar a teoria neoclássica da racionalidade, não apenas herdou dela o conceito formalista da monoutilidade, como também se propôs a defendê-lo ao insistir na importância da (suposta) neutralidade moral dos valores envolvidos na decisão racional.

\section{A TEORIA DA RACIONALIDADE LIMITADA DESCREVE, MAS NÃO EXPLICA, A DECISÃO NAS ORGANIZAÇÕES}

A síndrome comportamentalista, tal como exposta por Guerreiro Ramos (1989), impede que os agentes decisores julguem a natureza qualitativa de seus meios e fins de conduta. Presos em uma eterna rede de causa-efeito, já que fins sempre podem ser meios para fins maiores, os agentes decisores se comportam de modo fluido, como máquinas de somar. São apenas capazes de realizar cálculos de eficiência, mesmo que incompletos ou imprecisos, reduzindo tudo aquilo que está implicado em suas escolhas a um mesmo critério formal de suprautilidade.

Agindo como máquinas desprovidas de qualquer motivação intrínseca, os agentes decisores perdem a capacidade de justificar (tanto para os outros quanto para eles próprios) porque adotam certa conduta no lugar de outras possíveis. 0 comportamento torna-se, então, compulsivo (GUERREIRO RAMOS, 1989). Na verdade, uma única explicação pode ser encontrada e ela está baseada exclusivamente no critério da eficiência. Assim, determinado curso de conduta é escolhido no lugar de outros possíveis simplesmente por ser o que maximiza a realização de uma meta, independentemente de qual seja, "como se os critérios de economicidade fossem os únicos critérios da racionalidade" (GUERREIRO RAMOS, 1989, p. 122).

De acordo com Guerreiro Ramos (1989, p. 55), "pode ser deduzida uma certa epistemologia dessa condição, de acordo com a qual os processos e as mudanças têm que ser explicados como ativados exclusivamente por causas eficientes". Trata-se, segundo Procópio (2012), da mesma epistemologia positivista e operacionalista que apoia a Ciência Administrativa, tal como entendida por Simon (1979). Para Guerreiro Ramos (1989, p. 55), "essa, aliás, é a epistemologia em que se apoia a ciência social convencional" como um todo. Uma vez sob a égide dessa epistemologia, o máximo que a teoria da racionalidade limitada pode fazer, então, ao tentar explicar as decisões, é advertir para o fato de que as escolhas feitas pelos agentes podem não trazer a eficiência que deveriam em termos de resultados, uma vez que existem limites para a capacidade informacional e computacional daqueles que decidem.

Daí segue que a teoria da racionalidade limitada descreve as condições formais, mais ou menos favoráveis, dentro das quais as escolhas dos agentes decisores são feitas, mas não é capaz de explicar porque são feitas. Ela descreve o calculo utilitário de consequências e suas limitações, mas não explica porque ele é realizado. Dito de outro modo, ela descreve como os meios são selecionados dentro de condições limitantes, mas não explica como os fins são escolhidos com base em seu valor intrínseco. Por outro lado, argumenta Etzioni (1988, p. 138), "uma teoria produtiva deve lidar também com os próprios processos de formação de fins [...] e de proteção da supremacia dos fins sobre os meios. Ser eficiente pode ser somente tão bom quanto forem os objetivos que estão sendo eficientemente implementados". Afinal, questiona esse autor, para que é preciso ser eficiente?

Assim, vê-se que, sob o ponto de vista da descrição "exterior" do processo decisório, o modelo da racionalidade limitada pode realmente oferecer uma grande contribuição. Sob sua tutela, torna-se relativamente fácil perceber porque uma decisão não obteve êxito, por exemplo, por não ter o agente decisor considerado todas as variáveis envolvidas na escolha realizada, ou por 
não ter disposto ele do tempo e das informações suficientes para calculá-las e compará-las com a mínima precisão. Todavia, quando passa a ser necessário compreender "porque" tal agente privilegiou certos dados e fatos implicados na escolha realizada, em detrimento de outros que também deveriam ter sido considerados, aí se torna necessário revelar quais foram os critérios qualitativos de julgamento que ele empregou, uma vez que são esses critérios os verdadeiros responsáveis por direcionar seu olhar a certos aspectos do problema analisando, em detrimento de outros, aumentando ou diminuindo, então, sua capacidade analítica, ou seja, sua "racionalidade" (ETZIONI, 1988).

\section{A TEORIA DA RACIONALIDADE LIMITADA OCULTA A DIMENSÃO ÉTICA DAS ESCOLHAS HUMANAS}

Como as decisões humanas podem ser avaliadas como "corretas" ou "incorretas", "boas" ou "ruins"? Para Simon (1979), a avaliação da correção das decisões humanas é, assim como a própria tomada de decisão, uma questão puramente factual e nela não há espaço para apreciação ética e qualitativa, já que "não existe nenhuma maneira de demonstrar, empírica ou racionalmente, a correção das proposições éticas" (SIMON, 1979, p. 48).

As proposições factuais que, de acordo com Simon (1979, p. 48), "não podem ser derivadas das proposições éticas por nenhum processo de raciocínio", estão sujeitas a serem testadas empiricamente, ou seja, é possível saber objetivamente "se o que elas afirmam a respeito do mundo ocorre ou não, na realidade” (SIMON, 1979, p. 48). Assim, para Simon (1979, p. 51, grifo do autor),

[...] constitui uma questão puramente factual saber se as medidas que ele [o administrador] toma a fim de alcançar seus objetivos são medidas apropriadas. Saber se o fim em si mesmo é correto ou incorreto não constitui uma questão de fato exceto até o ponto em que o fim em causa acha-se jungido, por um a fim de, a outros fins.

Desse modo, complementa Simon (1979, p. 51), "é sempre possível avaliar as decisões nesse sentido relativo, podendo-se determinar, por exemplo, se elas são corretas à luz dos objetivos a que visam".

Ao argumentar desse modo, Simon (1979, p. 48) reconhece que, na prática, as decisões administrativas são um misto de elementos éticos e factuais, ou seja, "possuem, ao mesmo tempo, um conteúdo ético e um conteúdo factual". Isso porque, como afirma o próprio Simon (1989, p. 52), "a maior parte das proposições éticas vêm misturadas com elementos factuais".

Todavia, dentro da concepção de racionalidade de Simon, o elemento moral da decisão é sumariamente excluído, tanto do processo decisório quanto da avaliação da correção das decisões tomadas pelos agentes decisores. Como admite o próprio Simon (1979, p. 51), "falando num sentido estrito, não é a decisão em si que é avaliada, mas a relação puramente factual que é estabelecida entre a decisão e seus fins".

A decisão administrativa, assim como qualquer outra ação deliberativa realizada pelo homem, está baseada na capacidade subjetiva de julgar, comparar e escolher um dentre vários cursos de ação disponíveis, além de efetivamente agir na direção escolhida. Não há como negar que, sob o ponto de vista informacional e computacional, essa capacidade é realmente limitada. Mais do que isso, é possível conjecturar que se a racionalidade, tal como concebida por Simon, não fosse limitada, certamente não seríamos humanos. Todavia, essa capacidade de julgamento não se restringe, ao contrário do que sustenta a teoria da racionalidade limitada de Simon, apenas aos elementos factuais e quantitativos implicados nas opções de ação. Ao contrário, como sustenta Chanlat (1999, p. 26), apoiando-se em Michel Freitag (1996, p. 57-58), “na ordem propriamente humana, a questão dos valores precede e circunscreve sempre o sentido 'da questão de fato', é ela que Ihe designa um lugar significativo, e não o contrário".

A moralidade, entendida aqui como a conduta orientada pelo julgamento de "certo" ou "errado", "bom" ou "mau", "melhor" ou "pior" (DEWEY, 1964), é, por certo, algo irredutível em se tratando de decisões e ações humanas, dentre as quais se encontram as decisões e ações administrativas. Segundo Barnard (1979, p. 253), "todos os homens normais são seres 'morais'”. A moralidade também é algo irredutível quando tratamos das formas sociais por meio das quais os indivíduos interagem. Nesse sentido, "vale dizer que toda organização social humana tem uma moral" (LA TAILLE, 2006, p. 26). Por isso, o julgamento moral é algo inevitável para o ser humano (DEWEY, 1964). Nenhum indivíduo satisfatoriamente socializado pode abster-se de praticá-lo. Dito de outro modo, ninguém pode deixar de ser moral por pura e simples vontade (ETZIONI, 1988). 
Como bem observou Rest (1986, p. 8), "julgamentos morais parecem ocorrer naturalmente para as pessoas [...] Parece que é como se as pessoas fossem geneticamente feitas para fazer julgamentos morais ou como se fossem rapidamente condicionadas pela experiência social para fazê-los". Do mesmo modo, Dewey (1950, p. 279) já havia reconhecido, muito antes de Rest (1986), que "a conduta [moral] cobre todo ato que é julgado com referência ao melhor e ao pior e que a necessidade deste julgamento potencialmente se estende a todas as porções da conduta, exceto pelo erro de se fazer da moralidade um departamento separado da vida". Como notou o mesmo autor, em outra obra, "o comportamento humano parece ser influenciado, se não controlado, por considerações com as expressas nas palavras 'bom-ruim', 'certo-errado', 'admirável-horrível', etc. Toda conduta que não é simplesmente impulso cego nem rotina mecânica parece envolver valoração [moral]" (DEWEY, 2008b, p. 193). Grifo do autor.

Ao contrário de Simon, Dewey (1964, p. 110) ensinou que "não se pode traçar qualquer linha rígida e firme na conduta isolando o reino moral do reino não-moral". Não há uma ação propriamente moral, assim como também não há uma decisão propriamente moral, isolada da vida cotidiana das pessoas. Como reforçam Edel e Flower (2008, p. XIII) ao comentar as contribuições de Dewey, "a reflexão moral atinge toda e qualquer área da vida para encontrar o que é relevante para problemas específicos; a moralidade não é uma esfera isolada". De acordo com Provis (2010, p. 7), isso significa que "em muitas situações de tomada de decisão não é realista traçar uma linha entre fatos e valores para tratamento separado". Do mesmo modo, na pesquisa empírica realizada por Elm e Radin (2012, p. 325) constatou-se que, "contrariando o pressuposto comum, pode não haver distinção real entre os processos de tomada de decisão ética e outros tipos de tomada de decisão". Assim, "não existe, portanto, separação entre racionalidade moral e outros tipos de racionalidade (ELM e RADIN, 2012, p. 325). Grifo dos autores.

Desse modo, uma vez que as escolhas morais estão por toda parte, compreender o comportamento administrativo requer que se compreenda como age e decide moralmente o gestor. Moralidade e racionalidade não podem permanecer, então, isoladas.

\section{A TEORIA DA RACIONALIDADE LIMITADA NÃO CAPTA A VERDADEIRA ESSÊNCIA HUMANA E SOCIAL DA DELIBERAÇÃO}

Decisões humanas são eminentemente morais, ou seja, são guiadas por critérios éticos de julgamento capazes de qualificar como "boas" ou "ruins" as coisas e as ações (próprias e dos outros), além de medir sua suficiência ou insuficiência em termos quantitativos. Como observa Etzioni (1988, p. 26), "certamente, nem todos [...] julgamentos são éticos; eles podem, por exemplo, ser estéticos. De qualquer modo, os valores morais têm claramente um papel pivô na formação de muitos desses julgamentos", incluído aqueles de ordem factual e quantitativa. Além disso, argumenta Etzioni (1988, p. 67), "as evidências reforçam a visão de que não é produtivo considerar os compromissos morais como apenas mais uma fonte de preferência de consumo, sugerindo que eles são melhor compreendidos como uma categoria significativa e 'irredutível'".

De acordo com Dewey (1964, p. 121), "a deliberação moral não trata da quantidade de valor, mas da qualidade”. Mesmo as menores decisões, assim como aquelas amplamente embasadas em considerações técnicas, possuem, em alguma instância, uma dimensão moral. Nas palavras de Dewey (1964, p. 13), "cada ato tem um significado moral potencial porque é, através de suas consequências, parte de um todo de conduta maior".

A ética é entendida aqui, no sentido amplo, como qualquer reflexão, científica ou não, realizada por alguém a fim de descobrir o caráter moral de algo, ou seja, se algo é "bom" ou "ruim", "correto" ou "incorreto", "justo" ou "injusto" (DEWEY, 1964). Partindo da perspectiva de Dewey (1964), todo agente decisor capaz de refletir sobre sua própria conduta e apreciá-la a partir da sua inteligência é, justamente por isso, capaz de julgar a natureza moral de suas escolhas. Por conseguinte, está apto a praticar avaliações éticas.

Procópio (2012), baseando-se em Max Weber, argumenta que a avaliação moral de uma ação é própria da percepção de sentido subjetivo por parte de quem a conduz, ou seja, não ocorre quando o indivíduo se comporta exclusivamente determinado por compulsões exteriores, nem mesmo quando ele se comporta exclusivamente impelido por impulsos idiossincráticos. Nessas duas condições extremas e "não humanas", complementa Procópio (2012), os indivíduos não são capazes de apreciar qualquer tipo de "valor" em sua conduta e, portanto, deixam de ser agentes decisores.

Embora as coletividades, por si próprias, não deliberem, 
[...] as características da maioria das decisões e deliberações - a coleta de informações, seu processamento, a confecção de inferências e a formação de julgamentos - são profundamente afetadas e podem ser explicadas, em um nível significativo, pelas estruturas e processos coletivos (instituições e organizações) (ETZIONI, 1988, p. 185).

Desse modo, explica Etzioni (1988, p. 181), na prática, "o que as pessoas compram, quanto elas investem, quão duro elas trabaIham, e assim por diante - refletem amplamente sua sociedade, política, cultura e subcultura, classe, bem como as coletividades a que elas costumam pertencer". Isso também se aplica, por certo, a tudo aquilo que as pessoas avaliam como "bom" ou "ruim", "justo" ou "injusto", "correto" ou "incorreto" e seus respectivos critérios de julgamento. Afinal, "o comportamento racional não acontece no vácuo; ele requer uma personalidade, um contexto social e uma estrutura adequados" (ETZIONI, 1988, p. 154).

Ademais, a essência propriamente humana da deliberação se reflete na motivação dos agentes decisores e pode ser verificada justamente na relação que o indivíduo guarda com suas próprias ações. De acordo com Dewey (1964, p. 137, grifo do autor),

[...] a identidade do "eu" e de um ato [...] é a chave para a compreensão da natureza dos motivos e da motivação. A menos que se perceba e reconheça, teoricamente, essa união, o motivo será considerado alguma coisa exterior agindo sobre o indivíduo e induzindo-o a fazer algo. Quando esse ponto de vista é generalizado, leva à conclusão de que o "eu" é naturalmente e intrinsecamente inerte e passivo e, portanto, deve ser movido a agir por alguma razão fora de si mesmo. $O$ fato, porém, é que o "eu", com sua base vital de organismo, é sempre ativo; age em virtude de sua própria constituição, não precisando de promessa externa de recompensa ou ameaça de um mal para ser induzido a agir.

Daí segue que toda decisão acarreta consequências sobre o próprio indivíduo que decide, modelando ou reforçando seu "eu", além das consequências sobre os outros e sobre o ambiente exterior no qual ele atua. Cada decisão ajuda a reforçar ou enfraquecer o "eu" de quem decide. Mais precisamente, ajuda a reforçar ou enfraquecer, no "ser" de quem decide, os critérios subjetivamente utilizados para a valoração e para a escolha.

Todavia, como bem observou Etzioni (1988, p. 189), "as coletividades [...] são partes integrais das personalidades daqueles que se encontram nelas envolvidos, assim como essas personalidades são parte integrais das coletividades". Ou seja, "o indivíduo e a comunidade fazem um ao outro e dependem um do outro" (ETZIONI, 1988, p. 9, grifo do autor). Por isso, "o contexto social é, em grande medida, percebido como parte legítima e integral da existência individual" (ETZIONI, 1988, p. 5). Então, uma vez que os critérios éticos de julgamento não são somente subjetivos, mas, acima de tudo, socialmente compartilhados, cada decisão individual também repercute sobre a cultura, os hábitos e costumes, reforçando-os ou enfraquecendo-os lentamente. "Em suma, o que está realmente em jogo em qualquer deliberação séria não é uma diferença de quantidade, mas que tipo de pessoa alguém está para se tornar, que tipo de eu está sendo construído, que tipo de mundo está sendo criado" (DEWEY, 1950, p. 216-217).

A teoria da racionalidade de Simon, todavia, se abstém de considerar essa característica essencialmente humana e social da decisão. Adotando um viés mecanicista, ignora amplamente os fatos, tão bem notados por Etzioni (1988, p. 5), de que os "indivíduos agem dentro de um contexto social, que este contexto não é redutível a atos individuais e, mais significativamente, que o contexto social não é necessariamente ou totalmente imposto".

Ao ocultar a dimensão moral da escolha, anterior e determinante do próprio cálculo "racional" quantitativo, Simon oculta também o próprio "ser" humano, sua cultura, suas instituições e sua história. Por isso, a teoria da racionalidade de Simon não é capaz de captar a verdadeira essência humana e social da ação e da decisão administrativa, limitando-se a conceber o agente decisor como uma máquina que se comporta compulsivamente a partir de critérios formalistas extrínsecos (GUERREIRO RAMOS, 1989).

\section{A TEORIA DA RACIONALIDADE LIMITADA DESCREVE A DECISÃO A PARTIR DA NEGAÇÃO DA RACIONALIDADE}

Simon $(1979,1989)$ empreende um grande esforço teórico para tentar retirar a moralidade do processo decisório, buscando demonstrar que a racionalidade somente pode existir afastada de qualquer perspectiva ética. Todavia, o modo como Simon tenta negar a existência da moralidade na racionalidade é bastante controverso. Isso porque, assim como Etzioni (1988), 
Simon não deixa de reconhecer que escolhas humanas são eminentemente feitas com base em critérios éticos qualitativos e somente depois são aplicados critérios factuais quantitativos de valoração. Todavia, para Simon (1979, p. 51) a racionalidade diz respeito tão somente ao julgamento dos elementos "neutros" e quantitativos envolvidos nas escolhas. Na concepção de racionalidade de Simon não há espaço para avaliação qualitativa ou ética, uma vez que "não existe nenhuma maneira de demonstrar, empírica ou racionalmente, a correção das proposições éticas" (SIMON, 1979, p. 48). Assim, sob o ponto de vista de Simon $(1979,1989)$, a razão está sempre condicionada a operar mediante a existência de alguns pressupostos, axiomas ou regras de inferência "não racionais".

Como reconhece Simon (1979, p. 82), "a escolha individual ocorre num ambiente de pressupostos - premissas que são aceitas pelo indivíduo como bases para sua escolha - e o comportamento é flexível apenas dentro dos limites fixados por esses pressupostos". Esses pressupostos, dentre os quais se encontram aqueles de ordem ética, funcionam então como axiomas ou regras de inferência que os agentes decisores utilizam para orientar sua conduta, muito embora, segundo Simon, essa orientação esteja muito longe de ser uma reflexão propriamente racional. Para Simon (1989, p. 14), "os axiomas e as regras de inferência constituem, em conjunto, o fulcro onde assenta a alavanca do raciocínio; mas a estrutura específica desse ponto fulcral não pode ser justificada pelos métodos do raciocínio".

Na visão de Simon (1989), por serem elementos "pré-racionais" que condicionam o funcionamento da razão, esses axiomas e regras de inferência prejudicam o processo decisório na medida em que limitam a racionalidade dos agentes decisores. Orientam sua atenção a certos aspectos tendenciosos dos problemas decisórios, impedindo-os, então, de avaliar "racionalmente" todas as variáveis implicadas nas opções de escolha. Para Simon (1989), cuja concepção de racionalidade ainda está presa à concepção de racionalidade plena, esses elementos são, portanto, arbitrários e indesejados. Assim, afirma o autor ao se referir aos axiomas e regras de inferência, "este elemento não erradicável de arbitrariedade - este 'pecado original' [...] corrompe o processo de raciocínio e, portanto, também os seus resultados” (SIMON, 1989, p. 14).

O que segue dessa argumentação é que, para Simon, ser moral é ser irracional. Simon não apenas nega o fato - constatado por Schwartz (2016), Woiceshyn (2011), Provis (2010), Etzioni (1988), Dewey (1964), Dewey e Tufts (2008), La Taille (2006) e Gaudine e Thorne (2001) - de que, por ser uma faculdade inteligente de julgamento e atribuição de valor, a moralidade é parte integrante da racionalidade humana, como também não é capaz de reconhecer que, justamente por orientar a atenção do agente decisor, são os critérios éticos de julgamento que permitem a existência de qualquer "racionalidade".

Como bem nota Etzioni (1988, p. 148), "raramente a informação sozinha aponta para a escolha que deve ser seguida. Tipicamente, ela precisa ser avaliada e integrada com outros itens de informação que o agente já possui, projeções e interpretações devem ser adicionadas e conclusões devem ser obtidas"3. Por isso, sem a presença dos pressupostos, axiomas ou regras de inferência de ordem ética, os agentes decisores estariam condenados a vagar indefinidamente, a cada decisão que se fizesse necessária, pelo complexo, infinito e indefinido mundo dos fatos e dados "objetivos" sem qualquer orientação ou perspectiva de saída. Como complementa Lacey (2006, p. 262), "não é a natureza do mundo que nos leva a prestar atenção, primariamente, nos fatos [...], mas uma escolha altamente condicionada por valores éticos e sociais" 4 .

Assim, por mais sofisticada que pudesse ser a racionalidade do agente decisor, tal como concebida por Simon, ainda assim ela seria inútil diante da infinidade de variáveis e opções de ação com consequências igualmente infinitas e indefinidas. Afinal, de acordo com Simon (1989, p. 16), "a razão é totalmente instrumental. Não nos pode dizer para onde vamos; quando muito pode indicar-nos como lá chegar. É uma arma mercenária que pode ser posta ao serviço de qualquer dos nossos objetivos, bons ou maus".

Vê-se, então, que Simon descreve a decisão por uma negação da racionalidade e não pela afirmação de que a racionalidade humana só é possível a partir de critérios qualitativos e substantivos de julgamento. Na prática, os fatos e dados objetivos implicados nos problemas decisórios somente podem ser reconhecidos e levados em consideração pelos agentes decisores, na medida em que forem "focalizados" por meio de suas "lentes" morais. Pois dados e fatos "objetivos", somente surgem como partes de problemas a serem resolvidos depois que a conduta já dispõe de um sentido moral, e nunca o contrário.

Simon $(1979,1989)$ admite, então, que a decisão está baseada em critérios inalienáveis e preexistentes no indivíduo que vão além do próprio processo racional, tal como por ele compreendido. O que ele não admite, por conceber de modo demasiadamente reducionista a racionalidade, é que esses critérios fazem parte, eles mesmos, dos processos racionais humanos. Ao negar a existência da moralidade na racionalidade, Simon acaba por negar, então, a própria racionalidade.

${ }^{3}$ Eis a importância do "dever ser", tão evitado por Simon, no processo decisório.

${ }^{4}$ Eis o caráter promotor ou potencializador da racionalidade, oferecido pela perspectiva da moralidade. 


\section{SIMON E O CAMINHO PARA RUPTURA COM O PARADIGMA DA RACIONALIDADE PLENA}

Embora Simon tenha apresentado uma teoria da racionalidade ainda filiada ao pensamento neoclássico que ele mesmo se propôs a criticar, alguns de seus esforços para a compreensão do "comportamento administrativo" e da "razão nas coisas humanas" contribuíram para que fosse possível avançar na direção de uma teoria realmente nova da racionalidade. Assim, é importante reconhecer que Simon $(1979,1989)$ abordou alguns dos elementos que estão presentes na decisão moralmente orientada, embora tenha deliberadamente optado por não aprofundar a problemática da ética em sua teoria da racionalidade. Ele o fez em quatro momentos distintos: 1 ) ao reconhecer que as decisões são tomadas com base em premissas éticas preexistentes para o agente decisor, embora "irracionais" (esse ponto já foi suficientemente desenvolvido nos parágrafos anteriores); 2) ao reconhecer que decisões são mais do que problemas factuais; 3 ) ao reconhecer que as organizações e as instituições influenciam a racionalidade e o processo decisório dos indivíduos; e 4) ao reconhecer a existência da intuição e da emoção na decisão.

\section{DECISÕES SÃO MAIS DO QUE PROBLEMAS FACTUAIS}

Para Simon (1979, p. 195), "o administrador utiliza o critério da eficiência para resolver questões factuais". Todavia, Simon (1979) também reconhece que os problemas factuais não são os únicos enfrentados pelos administradores. "As decisões são algo mais que simples proposições factuais [...] elas possuem, ao mesmo tempo, um conteúdo ético e um conteúdo factual" (SIMON, 1979, p. 48).

Todavia, a posição epistemológica adotada por Simon (1979) - segundo a qual "uma ciência administrativa, como qualquer outra ciência, preocupa-se puramente com as afirmações de fato, não havendo nela, portanto, lugar para preceitos éticos" (SIMON, 1979, p. 265) - impediu esse autor de desenvolver uma teoria da racionalidade na qual os problemas éticos também entrassem nas "equações" do agente decisor. Por isso, Simon (1979, p. 52, grifo do autor) foi obrigado a postular, contrariando seus próprios achados, que "qualquer expressão que contenha um elemento ético, intermediário ou final, não pode ser descrita como correta ou incorreta e que o processo decisório deve partir de alguma premissa ética considerada preexistente".

Para fugir da contradição por ele mesmo criada, Simon (1979) opta, então, por separar artificialmente, para efeito de análise do processo racional, os elementos éticos e os elementos factuais envolvidos na decisão gerencial, preferindo dar ênfase aos segundos. O próprio Simon (1979, p. 55) reconhece a dificuldade em operar essa separação, quando afirma que, "na prática, a separação dos elementos éticos e factuais de um juízo só pode ser efetuada até certo ponto", uma vez que as ações e decisões humanas nunca estão desligadas de uma finalidade maior, um objetivo superior na cadeia meios-fins, representado por um "projeto" que é, por sua própria natureza, moral.

Uma das principais contribuições de Simon (1979) para a teoria moral da racionalidade se encontra justamente no reconhecimento dessa dificuldade. Como expõe o próprio Simon (1979, p. 192),

[...] pode-se admitir livremente que a eficiência [...] preocupa-se primordialmente dos meios e que um serviço eficiente pode sê-lo com respeito a uma ampla variedade de fins. Reconhecer, todavia, [...] que a adaptação dos meios aos fins constitui o único elemento do problema decisório que possui uma solução factual, não significa ficar indiferente quanto aos fins aos quais a eficiência serve.

Assim, para evitar o risco de "ficar indiferente" aos fins aos quais a eficiência serve e, com isso, causar potenciais danos humanos, sociais e ambientais, Simon (1979, p. 193) propõe que "outros critérios, de natureza ética, devem ser aplicados ao problema da avaliação" das alternativas de ação.

Mesmo de modo contraditório, Simon (1979) deixa claro, então, que o processo decisório deve incluir, no cálculo racional das alternativas de conduta realizado pelo agente decisor, não apenas critérios de julgamento de natureza factual, mas também critérios de julgamento de natureza ética.

Ao admitir que decisões são mais do que problemas meramente factuais, Simon (1979) abre as portas para uma teoria moral da racionalidade, na qual a percepção e avaliação das opções de conduta por parte dos agentes decisores também podem ser conduzidas com base em padrões ou princípios éticos de julgamento. 


\section{AS ORGANIZAÇÕES E AS INSTITUIÇÕES INFLUENCIAM A RACIONALIDADE E O PROCESSO DECISÓRIO DOS INDIVÍDUOS}

A preocupação de Simon com os limites da racionalidade vai além das restrições informacionais e computacionais dos agentes decisores. A todo momento, Simon (1979) argumenta que a racionalidade individual deve estar integrada a uma racionalidade organizacional, já que os esforços desempenhados por cada um dos membros individuais da organização devem servir para viabilizar os "objetivos administrativos" do sistema como um todo. Assim, argumenta Simon (1979), se o agente decisor, individualmente pensado, é incapaz de tomar decisões plenamente racionais, então, as organizações devem ser administradas para favorecer o ganho de racionalidade, ou seja, eficiência na consecução de seus "objetivos administrativos" como um todo. Afinal, de acordo com Simon (1979, p. 252, grifo do autor),

[...] a teoria administrativa é necessária porque existem limites práticos à racionalidade humana, e porque essas limitações não são estáticas, mas dependem do meio organizativo no qual o indivíduo toma suas decisões. A tarefa da administração consiste, portanto, em preparar esse meio ambiente, de forma a permitir que o indivíduo se aproxime o mais que possa da racionalidade (avaliada em termos dos objetivos da organização) em suas decisões.

Desse modo, Simon (1979) argumenta que as organizações podem e devem influenciar a racionalidade dos indivíduos de duas formas. Primeiramente, fornecendo-lhes os "propósitos comuns" (que são os propósitos da sua administração), que servem como guias maiores para a orientação e confluência dos diversos esforços individuais realizados dentro dela. Esses "objetivos comuns", por sua vez, podem ser interpretados como aquilo que se discute, na área da Administração Estratégica sob o rótulo de "missão" (CERTO e PETER, 1993). Vão derivando objetivos cada vez mais específicos, na medida em que se desdobram em metas a ser alcançadas pelos níveis hierárquicos inferiores da organização, em intervalos de tempo mais curtos.

Entretanto, é importante ressaltar que, sob o ponto de vista de Simon (1979), os indivíduos são esvaziados da responsabilidade de formular os objetivos que sua própria ação "racional" deve perseguir dentro das organizações, cabendo à administração definir suas metas de trabalho por meio da relação de autoridade. A autoridade é definida, de acordo com o próprio Simon (1979, p. 131), como "o poder de tomar decisões que guiam as ações de outrem". Assim, explica Simon (1979, p. 131, grifo do autor), especialmente nas organizações mais complexas, o indivíduo "permite que a decisão comunicada por um outro guie sua própria escolha (isso é, sirva de premissa para essas escolhas) sem deliberação de sua parte sobre a oportunidade dessas premissas". Entre os diversos elos hierárquicos, as decisões tomadas pelos agentes superiores vão se transformando nas premissas decisórias dos agentes inferiores e, assim, a administração assegura o controle sobre o que acontece na organização.

A despeito da importância e do alcance da "autoridade", Simon (1979) admite que a organização não é capaz de decidir pelo indivíduo. Os objetivos que ela lhe impõe servem apenas como orientações para suas escolhas que, algumas vezes, podem desviar das escolhas "racionais" esperadas pela administração.

A influência exercida pela organização sobre o indivíduo pode ser interpretada, por conseguinte, não como determinação por parte dela das decisões do indivíduo, mas sim de algumas das premissas em que este deverá basear suas decisões [...] Quando o indivíduo se decide por determinado curso de ação, é possível que algumas das premissas em que baseia essa decisão lhe tenham sido impostas pela autoridade que a organização exerce sobre ele (SIMON, 1979, p. 129, grifo do autor).

A segunda forma de influência que, de acordo com Simon (1979), as organizações exercem sobre a racionalidade dos indivíduos, contém um elemento de controle ainda mais evidente do que a primeira. Baseia-se, por seu turno, no oferecimento de estímulos, por parte da administração, capazes de provocar respostas "racionais", condicionadas tanto pela força do hábito de trabalho quanto pela força das rotinas gerenciais às quais estão sujeitos os indivíduos nas organizações e, não obstante, condicionadas também pelas instituições supraorganizacionais como a família, a escola e o Estado que, segundo Simon (1979), definem, em um nível mais basilar, os papéis sociais e os comportamentos esperados dos indivíduos no trabalho.

A partir do treinamento, da divisão do trabalho em tarefas "especializadas" menores e mais específicas, voltadas a objetivos igualmente pequenos e específicos, do estabelecimento de padrões de desempenho, da comunicação e da autoridade, a administração dispõe, como detalha Simon (1979), dos mecanismos necessários para provocar nos indivíduos respostas adequadas às demandadas da eficiência. Todos esses esforços fazem com que o indivíduo adquira "conhecimentos, habilidades, identificações ou lealdades que lhe permitem tomar decisões, tal como a organização desejaria que ele decidisse" (SIMON, 1979, p. 108). 
As instituições supraorganizacionais - definidas por Simon (1979, p. 137) como "regras que especificam os papéis que determinadas pessoas assumirão, sob determinadas circunstâncias, em relação aos demais" - embora não estejam sob o controle direto da administração, podem ser igualmente usadas por ela para provocar respostas "racionais" nos indivíduos que trabalham nas organizações instrumentais. Assim, explica Simon (1979), a lealdade do empregado pode ser substancialmente ampliada se a administração souber estimular corretamente a docilidade inerente ao papel de "empregado", papel este que, ainda de acordo com Simon (1979), é socialmente determinado.

Finalmente, ao tratar a organização como um "agente racional", Simon (1979) transfere a visão mecanomórfica de indivíduo para a própria organização, já que, para ele, as decisões tomadas dentro dela por uns são premissas decisórias para outros. De acordo com Simon (1979, p. 131), "a análise de todas as classes de comportamento organizado demonstra que esse tem êxito quando cada um dos indivíduos coordenados [...] torna o próprio comportamento dependente do comportamento dos outros".

Simon (1979) adota, então, de uma perspectiva behaviorista, baseada na relação causal estímulo-resposta induzida em um organismo (empregado) condicionado tanto pela organização quanto pelas instituições supraorganizacionais, para prescrever como a administração pode fazer o indivíduo ser "racional". Como reconhece o próprio Simon (1979, p. 131), "a relação de autoridade pode ser definida, portanto, em termos puramente objetivos e behavioristas, envolvendo o comportamento tanto do superior como do subordinado" ${ }^{\prime \prime}$.

Mais uma vez, Simon (1979) minimiza a importância da subjetividade para explicar o comportamento humano nas organizações, atribuindo a elementos extrínsecos o papel de promotores da "racionalidade". De fato, Simon (1979) reconhece a influência organizacional e institucional sobre a conduta individual, embora o faça somente para justificar como a racionalidade dos agentes decisores pode ser ampliada dentro das organizações, por meio de estímulos oferecidos pela administração. Se o indivíduo não é capaz de ser plenamente racional sozinho, na organização ele pode ter sua racionalidade aperfeiçoada, mesmo que dentro de um aspecto pequeno e específico dos problemas decisórios. Por conseguinte, a organização como um todo pode ser "racional" ou, ao menos, pode aproximar-se mais da racionalidade plena do que qualquer indivíduo isolado. "Os sistemas de comportamento a que chamamos de organização são imprescindíveis, portanto, à consecução da racionalidade humana num sentido amplo" (SIMON, 1979, p. 107). Por certo, para Simon (1979, p. 107) “o indivíduo racional é, e deve ser, uma pessoa organizada e institucionalizada".

A despeito de sua proposta behaviorista de intervenção sobre o comportamento humano organizado, baseada em uma concepção extrínseca de motivação, Simon (1979) reconhece a importância de um elemento essencial da decisão, intimamente ligado à moralidade, a saber, as instituições supraorganizacionais de onde vêm parte dos padrões ou princípios morais de valoração que os indivíduos utilizam para avaliar as diversas alternativas de ação diante de um problema. Nesse sentido, Simon corrobora a constatação de Etzioni $(1988$, p. 4) segundo a qual "decisões individuais frequentemente refletem, em grau significativo, processos e atitudes coletivas".

\section{INTUIÇÃO E EMOÇÃO ESTÃO PRESENTES NA DECISÃO}

A despeito da racionalidade limitada, os administradores continuam tomando decisões cotidianamente nas organizações, alguma delas surpreendentemente corretas sob o ponto de vista da eficiência. Como isso seria possível? De acordo com Simon (1989), isso é possível, em parte, devido à intuição.

Segundo Simon (1989), a intuição está associada à percepção, baseada em registros históricos simplificados de acontecimentos semelhantes, armazenados no repertório cognitivo do agente decisor, que este agente utiliza para fazer sua escolha diante da impossibilidade de comportar-se de modo propriamente racional, ou seja, examinando sistematicamente todas as alternativas possíveis de ação e antevendo todas as suas consequências. A intuição, explica Simon (1989), depende da experiência. Quanto maior a experiência do agente decisor no trato de certos problemas, maior será sua "racionalidade intuitiva", ou seja, maior será sua capacidade de encontrar soluções acertadas sem, entretanto, dispor da onisciência e onipotência, características da racionalidade plena.

5É importante ressaltar que essa perspectiva extrínseca de motivação é incompatível com aquela adotada por Dewey (1964, p. 139), segundo a qual “motivo [...] não é impulso para a ação ou algo que incite a fazer alguma coisa. É movimento do 'eu' como um todo [...]". 
Admitir que os gestores utilizam intuição em suas decisões significa admitir que eles são capazes de decidir em condições de incerteza e falta de informação. A intuição, portanto, está intimamente associada à racionalidade limitada. Nas palavras de Simon (1989, p. 47),

[...] a teoria intuitiva é, de fato, uma componente da teoria comportamental [da racionalidade limitada]. Realça os processos de conhecimento subjacentes às capacidades que os seres humanos podem adquirir através da acumulação de experiências e do reconhecimento de situações nas quais as suas experiências são relevantes e adequadas.

Como reforçam Luppe e Angelo (2010, p. 86), "o princípio da racionalidade limitada assume que, para lidar com as complexidades do mundo real, um indivíduo deve construir um modelo simplificado para cada situação". Do mesmo modo, de acordo com Etzioni (1988, p. 118),

[...] frente à limitada habilidade que os seres humanos têm para processar informação, e frente ao mundo complexo que eles precisam enfrentar (como Simon indicou), as pessoas usam vários esquemas heurísticos para simplificar o mundo complexo e, assim, poder lidar com ele.

Como já havia admitido o próprio Simon (1979, p. XXIV), "o homem administrativo reconhece [...] que o mundo por ele percebido é apenas um modelo drasticamente simplificado do agitado e confuso mundo real". Por isso, "o homem administrativo é capaz de tomar decisões guiadas por regras empíricas relativamente simples, que não sobrecarregam sua capacidade [limitada] de pensar" (SIMON, 1979, p. XXV). Como complementam Hayibor e Wasieleski (2009, p. 153-154),

[...] quando as pessoas fazem julgamentos em condições de incerteza, elas tendem a evitar análises de dados exaustivas; ao invés disso, elas frequentemente empregam heurísticas, que representam mecanismos cognitivos que permitem "atalhos" no processo de tomada de decisão.

Os "atalhos" e "simplificações" heurísticas, por sua vez, surgem ao agente decisor na forma de "intuição" ou "instinto" (MOTTA e VASCONCELOS, 2004) em um processo "racional" de percepção que, de acordo com Simon (1989) não é frio, mas temperado com a emoção característica da descoberta da solução para um problema decisório complexo.

Simon (1989), então, associa a emoção à intuição ao se referir à capacidade individual de percepção e escolha de soluções relativas aos problemas decisórios. Assim, emoção e intuição estão juntas no processo de julgamento que ocorre sob a tutela da racionalidade limitada, segundo esse autor. Em suas palavras, "a teoria intuitiva reconhece que o pensamento humano é frequentemente afetado pela emoção e foca a questão da sua função na concentração da atenção humana em problemas específicos e em ocasiões também específicas" (SIMON, 1989, p. 47).

Para Simon (1989), a emoção tem relação com a baixa capacidade que o agente decisor possui para se concentrar, com a mesma intensidade, nas mais diversas opções de conduta a ele disponíveis no momento da decisão. Por isso, "a emoção reveste-se de particular importância, em virtude da sua função seletiva em relação a determinados aspectos do nosso meio ambiente, enquanto focos da nossa atenção" (SIMON, 1989, p. 42). Todavia, uma vez que a emoção chama a atenção do agente decisor para certos aspectos da escolha em detrimento de outros que poderiam ser igualmente importantes, ela figura como um limitador da racionalidade perfeita (MOTTA e VASCONCELLOS, 2004).

Ao refletir sobre a importância da emoção nos processos racionais, Simon (1989, p. 15) reconhece que "a maior parte dos seres humanos é capaz de atender melhor aos problemas, de pensar mais a sério neles, de receber impressões mais profundas e mais duradouras, se a informação for apresentada num contexto emocional - uma espécie de condimento quente". Por isso,

[...] uma teoria comportamental da racionalidade, com a sua preocupação pelo foco de atenção como principal determinante da escolha, não dissocia a emoção do pensamento humano, nem o faz de modo a subestimar os poderosos efeitos da emoção ao ser estabelecida a ordem para a resolução de problemas humanos (SIMON, 1989, p. 42-43).

Vê-se então que, assim como ocorre com a intuição, a emoção, segundo Simon (1989), também faz parte do modelo da racionalidade limitada. Para Simon (1989) não há separação entre emoção "quente" e raciocínio "frio" no processo de tomada de decisão. Aqui, Simon possibilita avanços a passos largos na direção de uma teoria moral da racionalidade, pois, como já havia notado Dewey (1964, p. 116), 
[...] um julgamento moral, por mais intelectual que seja, deve, pelo menos, ser avivado pelo sentimento, se tem que influenciar sobre o comportamento. O ressentimento, desde a voraz execração e aversão até a leve repugnância, é ingrediente necessário ao conhecimento do mal que é o verdadeiro conhecimento. Afeição, desde o amor intenso até a uma leve estima, é ingrediente em todo conhecimento atuante, em toda apreensão, do bem. É, porém, ir muito longe dizer que tal apreciação pode dispensar todo elemento cognitivo.

Com efeito, decisões racionais não são tomadas em campo exclusivamente afetivo nem em campo exclusivamente intelectual (GAUDINE e THORNE, 2001). Como bem notou Etzioni (1988, p. 104), "quando o afeto é muito baixo, decisões podem não ser tomadas quando é racional proceder. Quando o afeto é muito alto, ele tende a interromper as deliberações. Em níveis moderados, o afeto tende a facilitar a tomada de decisão".

Ao incorporar a emoção nos processos racionais, Simon (1989) acaba por reconhecer, assim como fez Etzioni (1988), que o afeto é um facilitador ou promotor do comportamento inteligente "real" ou possível, além de ser um limitador da racionalidade plena "ficcional". Reconhece, também como fez Etzioni (1988, p. XI), que: "basear-se em emoções [...] é frequentemente um caminho usual e não distorcido de se fazer escolhas e produzir decisões efetivas". Todavia, a importância da intuição e da emoção se justifica, de acordo com Simon (1989), exatamente pela limitação da racionalidade. Se a racionalidade humana não fosse limitada, nem a intuição nem a emoção seriam necessárias. A atenção dada pelo indivíduo aos elementos envolvidos nas escolhas não seria seletiva e nenhum esquema cognitivo precisaria ser utilizado para "simplificar" a realidade complexa da decisão.

Além disso, há outra limitação no entendimento de Simon sobre a importância da intuição na deliberação que afasta sua teoria da decisão de uma teoria capaz de abranger os aspectos éticos das escolhas e ela se relaciona com a "acomodação". Por simplificar a realidade complexa da decisão e poupar os indivíduos de todo o exaustivo processo da racionalidade plena, as heurísticas "confortam" os agentes decisores. Por isso, Simon (1979, p. 6) acaba por admitir que "toda decisão é, até certo ponto, matéria de acomodação". Todavia, se decisões pressupõem acomodação, como os conflitos e dilemas morais que frequentemente surgem em decisões complexas, não rotineiras e cheias de incerteza podem ser explicados dentro da teoria da racionalidade limitada?

Julgamentos morais, assim como qualquer processo de valoração, de caráter ético ou não, estão sujeitos a simplificações e podem ser realizados por meio de "atalhos"6. Todavia, assumir que todo julgamento moral está baseado em estratégias de simplificação da realidade é uma generalização que as ideias de Dewey $(1950,1964,2008 b)$ sobre valoração e deliberação não permitem fazer. Embora os princípios ou padrões morais possam conter, até certo ponto, como explica Woiceshyn (2011), simplificações históricas de problemas semelhantes, eles não necessariamente servem como "atalhos" para a tomada de decisão. Ao contrário, eles podem revelar, quando utilizados pelos agentes decisores nos julgamentos das coisas e ações, os potenciais conflitos ou dilemas morais que suas escolhas podem acarretar.

Diferentes dos processos heurísticos que, por estarem ainda baseados na concepção de racionalidade limitada (LUPPE e ANGELO, 2010; HAYIBOR e WASIELESKI, 2009; MOTTA e VASCONCELLOS, 2004; ETZIONI, 1988), sugerem que a decisão é "matéria de acomodação", os julgamentos morais nem sempre simplificam o processo decisório nem confortam o agente decisor. $\mathrm{O}$ uso dos princípios ou padrões morais no processo de valoração muitas vezes estimula o agente decisor a buscar mais informações sobre o problema decisório em questão. Tais padrões ou princípios provocam, perturbam e, algumas vezes, mostram uma realidade empírica desconcertante para o agente decisor. Eles podem revelar dados e fatos contraditórios em suas escolhas, dados e fatos estes que tal agente, muitas vezes, não gostaria de saber. Afinal, o princípio ou padrão moral "dá, ao agente, a base para encarar e examinar determinada questão ao surgir dela. Ele descortina-lhe certos aspectos possíveis do ato; previne-o contra a adoção de um rápido ou parcial ponto de vista sobre o ato" (DEWEY, 1964, p. 128).

Portanto, reconhecer a existência da intuição e da emoção na tomada de decisão racional, do modo como fez Simon (1989), ainda não é suficiente para revelar a orientação propriamente moral dessa decisão. Ademais, no modelo da racionalidade limitada de Simon, não apenas a intuição e a emoção, mas também as premissas éticas preexistentes nas decisões (que devem

${ }^{6}$ Baseando-se no modelo de decisão ética de Jones, Hayibor e Wasieleski (2009) demonstram, por meio de dois estudos empíricos, como a heurística da disponibilidade pode afetar a percepção dos indivíduos sobre um problema moral. 
ser fornecidas ao indivíduo pela organização) e as instituições supraorganizacionais, junto com seus respectivos hábitos de conduta (que devem ser extrinsecamente estimulados nos indivíduos a fim de gerar um comportamento "racional"), todos têm um sentido negativo no que se refere ao alcance da racionalidade, ou seja, existem ou são importantes apenas devido ao fato das pessoas serem incontornavelmente limitadas ou pouco racionais em seus julgamentos e escolhas.

Reconhecer a real essência da racionalidade humana não se trata, meramente, de reconhecer que existem limites para uma racionalidade plena, fictícia e não humana, mas de admitir que as decisões humanas são eminentemente tomadas tendo como base critérios ou princípios de julgamento qualitativos e, por certo, também intuitivos e emotivos até certo ponto, ligados às noções sociais de "bem" e "mal", "correto" ou "incorreto", "melhor" ou "pior".

Longe de atuarem como fatores limitadores da racionalidade, esses critérios éticos de julgamento ampliam o alcance da compreensão do agente sobre os problemas decisórios complexos e não rotineiros, muitas vezes rodeados por dilemas e conflitos, onde a elaboração intelectual realmente tem importância maior do que a simplificação e a acomodação, trazendo para a decisão aquilo que ela tem de mais humano e social. Dito de outro modo, tais critérios morais, de caráter normativo e afetivo, como os entende Etzioni (1988), indissociáveis de toda e qualquer atividade genuína de avaliação, julgamento e escolha humana, são os verdadeiros promotores do comportamento racional daqueles que decidem.

\section{ELEMENTOS PARA UMA TEORIA MORAL DA RACIONALIDADE}

Toda escolha está baseada em julgamentos de "valor", mas nem todo "valor" encontrado pelo indivíduo que avalia as opções de conduta disponíveis é, necessariamente, um "valor moral". Como explica Dewey (1964, p. 111, grifo do autor),

[...] julgamentos morais, sejam o que forem mais, são uma espécie de julgamento de valor. [...] Julgamentos de valor não se limitam a questões explicitamente morais em seu significado. Ao considerarmos poemas, quadros e paisagens, do ponto de vista de sua qualidade estética, o julgamento refere-se a valores. Avaliam-se os homens de negócio quanto a sua posição econômica, ao darem crédito, etc. [...] Artigos de mobiliário são julgados úteis, confortáveis ou o contrário disso. [...] Quando pronunciamos o julgamento "bem" ou "mal", calculamos em termos de valores. Quando julgamos declarações de outros, sejam feitas em conversação casual ou em discursos científicos, e nos pronunciamos serem "verdadeiras" ou "falsas", estamos fazendo julgamentos de valor. De fato, o principal embaraço em dar exemplos dos julgamentos de valor está em vermo-nos, constantemente, empenhados em fazê-los.

De acordo com Dewey (1964, 2008b), nenhuma diferença entre um julgamento "ético" e um julgamento "factual" pode ser encontrada no próprio processo de avaliação e atribuição de valores, quando se trata de decisões humanas. Como explica o autor,

[...] a deliberação moral difere de outras formas, não como processo de formar julgamento e de chegar ao conhecimento, mas na espécie de valor sobre o qual se cogita. O valor é técnico, profissional, econômico, etc., quando nele se pensar como algo que se possa visar e atingir por meio de ter, de possuir; como algo a ser conseguido ou não. $\mathrm{O}$ mesmo objeto terá precisamente valor moral quando se julga que faz diferença no "eu", ao determinar o que um indivíduo será ou invés de, meramente, o que terá (DEWEY, 1964, p. 121).

A separação entre "fato" e "valor", sustentada por Simon $(1979,1989)$, implica bem mais do que uma simples tentativa de distinção entre tipos diferentes de julgamento. Implica, sim, uma completa e radical dicotomia, na qual "julgamentos de fatos" e "juízos de valor" devem ser mutuamente excludentes. De acordo com Putnam (2002), tal dicotomia baseia-se em uma simplificação empirista, herdada da ideia já há muito desafiada pela ciência contemporânea, ideia segundo a qual os "fatos" somente podem existir se puderem ser captados diretamente pelos cinco sentidos humanos, sem a mediação subjetiva do observador e sem qualquer mediação cultural ou institucional. Segundo Provis (2010), a ideia de que "fatos" e "valores" são distintos e que, portanto, devem ser tratados de modo igualmente distinto, remonta a um posicionamento positivista que vem sendo amplamente criticado. H. Putnam (2002) evidenciou que por trás da noção de "fato", tal como empregada 
por Simon (1979), esconde-se a ideia de "matéria", como se "fato" fosse sinônimo de "fato material" e como se "premissas fatuais" fossem proposições sobre aquilo que existe materialmente no mundo e "premissas éticas" fossem proposições sobre aquilo que existe simbolicamente no mundo.

Ao criticar a dicotomia fato/valor, Putnam (2002) argumenta que um dos mais rudes e consagrados argumentos epistemológicos de defesa dessa polarização radical se relaciona com a dúvida sobre a existência de "fatos morais". Segundo o questionamento dos positivistas lógicos, expõe o autor, como poderiam existir fatos morais se não dispomos de órgãos capazes de percebê-los assim como dispomos, por exemplo, de olhos que nos tornam capazes de perceber a cor amarela? De acordo com Putnam (2002, p. 102, grifo do autor),

[...] a fraqueza desse argumento repousa sobre sua ingenuidade acerca da percepção. [...] mesmo a percepção de cores parece pressupor um processo de aquisição da habilidade para discriminar as cores e não apenas a posse dos olhos. Mas considere a questão paralela: "Como nós podemos falar que as pessoas estão eufóricas? Afinal, nós não temos órgãos sensíveis para detectar a euforia". O fato é que nós podemos falar que outras pessoas estão eufóricas, e algumas vezes nós podemos até ver que outras pessoas estão eufóricas. Mas nós somente podemos fazê-lo depois de termos adquirido o conceito de euforia. A percepção não é algo inocente; ela é um exercício de nossos conceitos [...]. Uma vez que eu tenha adquirido o conceito de euforia eu posso ver que algumas pessoas estão eufóricas e, similarmente, uma vez que eu tenha adquirido o conceito de pessoa amigável, ou pessoa maliciosa, ou pessoa gentil, eu posso às vezes ver que alguém é amigável, ou malicioso, ou gentil.

No que se refere aos "fatos morais", segue o mesmo. Segundo Dewey (1964), os fatos morais, por mais emotivos ou intuitivos que possam inicialmente parecer, são igualmente perceptíveis à consciência dos indivíduos e estão igualmente sujeitos ao escrutínio da razão, entendida por esse autor como "inteligência". Todavia, para que se possa saber se uma coisa ou ação é boa ou não, é preciso antes dominar os "conceitos" de "bem" que se relacionam com a avaliação daquela coisa ou ação, dentre os quais se destacam os padrões ou princípios éticos (DEWEY, 1964).

Ao contrário do que presume Simon, ao utilizar a razão o agente decisor não é capaz de fazer uma avaliação propriamente "factual" separada de uma avaliação propriamente "ética" de suas opções de conduta (PROVIS, 2010). Ele não é capaz de separar terminantemente o "ser" do "dever ser", nem mesmo o que é material do que é simbólico. Por outro lado, ele emprega diversos critérios de julgamento para tentar conhecer o "valor", tanto "factual" quanto "moral", das coisas (PROVIS, 2010; ETZIONI, 1988; DEWEY, 1964). Por isso, Dewey (1964, 2008b) sustenta que a avaliação moral e a avaliação factual de um mesmo objeto não são mutuamente excludentes. Como complementa Provis (2010), embora a realidade moral possa se diferenciar, em alguma instância, da realidade material, ambas fazem parte do mesmo contexto no qual agem e decidem os indivíduos. Assim, ambas as dimensões ("factual" e "moral") da mesma realidade são por eles consideradas e avaliadas "empiricamente", "objetivamente" ou "factualmente". Ademais, ainda de acordo com Provis (2010), na prática isso acontece simultaneamente, no mesmo processo de avaliação realizado pelo indivíduo. Por conseguinte, argumenta Putnam (2002), "valoração" e "descrição" são interdependentes no processo humano e social de julgamento e escolha.

Além disso, "reconhecer que nossos julgamentos demandam validade objetiva e reconhecer que eles são modelados por uma cultura particular e por uma situação problemática particular não são coisas incompatíveis" (PUTNAM, 2002, p. 45). Assim como o conceito socializado de "amarelo", os conceitos morais são parte da nossa cultura e instituições. Como explica Putnam (2003, p. 376), "a moral implica uma interação com um meio que compreende outros seres humanos. A moral é social. Só nos tornamos e só somos um agente moral se nos relacionamos com o outro". Afinal, complementa Coltro e Santos (1998, p. 7), "ninguém nasce moral, mas torna-se moral".

A valoração moral, ou seja, a atribuição de "peso" moral às diversas opções de conduta passíveis de escolha, está ligada à capacidade que o agente decisor possui para reconhecer como "melhores" ou "piores", "bons" ou "ruins", "importantes" ou "não importantes" seus elementos, diante de algum ou de diversos padrões ou princípios éticos intersubjetivos. Como bem observaram Coltro e Santos (1998, p. 7), "muito embora o agente ético seja a pessoa, o indivíduo, a natureza da ética é primordialmente social", uma vez que ela depende de padrões ou princípios de julgamento socializados. Afinal, como já havia notado Etzioni (1988, p. 4), "decisões individuais frequentemente refletem, em grau significativo, processos e atitudes coletivas". 
Embora os princípios ou padrões éticos de julgamento sejam referências "ideais", ou seja, embora estejam presentes no "eu" de quem decide, eles não são meramente subjetivos, mas intersubjetivos, ou seja, são compartilhados por todos aqueles que dividem o mesmo espaço institucional. Na prática, isso significa que aquilo que um indivíduo reconhece como "bom", "justo" ou "correto" não é algo meramente pessoal ou idiossincrático. Embora o julgamento ético seja, em si, operado pelo indivíduo e, por isso, esteja relativamente sujeito à sua subjetividade, os critérios de avaliação por ele utilizados são compartilhados em seu grupo. Eis a dimensão social dos julgamentos éticos.

Segundo Bird e Waters (1987, p. 1),

[...] padrões morais são guias que se impõem para o comportamento interpessoal. [...] Padrões morais se impõem e, por isso, são normativos a ponto dos indivíduos se sentirem obrigados a se conformarem com eles ou a darem boas razões ao agirem de modo desviante em relação a eles.

Dado seu caráter intersubjetivo, Bird e Waters (1987) relacionam o conceito de padrão moral à noção de convenção moral. Em suas palavras,

[...] convenções morais referem-se a padrões normativos culturalmente compartilhados que frequentemente são vistos como ideias postulares do senso comum, respeitadas e justificadas por práticas costumeiras e sabedoria convencional [...] Quando padrões morais são comunicados como convenções culturais, eles são invocados e utilizados como se fossem largamente autoevidentes e verdadeiros, como se um consenso existisse no que diz respeito à sua validade (BIRD e WATERS, 1987, p. 12).

Vê-se, então, que os padrões morais fazem parte da estrutura institucional elementar dos grupos, são historicamente constituídos como convenções sociais e, portanto, exercem influência essencial sobre os julgamentos e as ações dos seus membros. Na qualidade de convenções sociais, os padrões morais se integram à "cultura" do grupo, unindo e identificando seus membros por meio do significado moral que oferecem às suas escolhas e seus comportamentos.

Nesse sentido, é importante observar que os padrões morais, por pertencerem à cultura e às instituições sociais, não são estáticos, mas têm sua existência e legitimidade condicionadas pela história. Por certo, assim como as instituições, que têm sua história (BERGER e LUCKMANN, 1985), os padrões institucionalizados de conduta também possuem raízes sócio-históricas (DEWEY, 2008a) e, por isso, também não podem ser corretamente compreendidos fora de seu contexto mais amplo. Por isso, o que é visto em certa comunidade como "bom", "justo" ou "correto" em certa época pode não ser mais visto assim em outros tempos ou em outras comunidades.

De acordo com Dewey (1964, p. 127), a função do princípio ou padrão moral é "fornecer pontos de vista e métodos que capacitem o indivíduo a fazer, para si, uma análise dos elementos do bem e do mal na situação particular em que se encontra". Apesar do seu caráter normativo, Dewey (1964) se empenha em demonstrar que padrões ou princípios morais não podem ser entendidos como regras morais que visam meramente a prescrever o que é "bom" ou "certo" em termos de conduta. Ao contrário das últimas, explica o autor, "um princípio moral [...] não é ordem para agir ou para reprimir um ato em determinado sentido: é instrumento para analisar situações especiais, sendo o certo ou o errado determinado pela situação em sua inteireza e não pela regra como tal" (DEWEY, 1964, p. 128, grifo do autor). Por isso, concordam Bird e Waters (1987, p. 1), "independentemente da forma, os padrões morais normativos influenciam persuasivamente o comportamento e não coercitivamente".

Com efeito, padrões morais fazem parte do "eu" de quem avalia e toma decisões. De certo modo, somos nossos padrões e, ao utilizar determinado padrão ou princípio moral para avaliar o que é importante em um possível curso de ação, o indivíduo reforça seu "eu" moral, aquilo que se conhece como "caráter" ou como "personalidade ética" (LA TAILLE, 2006). Desse modo, os padrões morais adquiridos a partir da sociedade modelam nossa personalidade moral, assim como seu uso ou desuso mais intenso pelos indivíduos pode repercutir paulatinas alterações nas instituições a partir das quais tais padrões são absorvidos. Por isso, afirma Dewey (1964, p. 143), "a verdadeira questão moral está em saber qual a espécie de 'eu' que está sendo promovida e formada. E a questão surge tanto em relação a nosso próprio 'eu' quanto ao de outros".

Diferentemente dos critérios de julgamento de natureza meramente quantitativa, o padrão moral é um misto de conhecimentos (tanto tácitos quanto explícitos) e sentimentos interligados de um modo complexo (SCHWARTZ, 2016; WOICESHYN, 2011). 
Sua interiorização pelo indivíduo se dá a partir de experiências emocionalmente carregadas, assim como seu uso implica certa carga emotiva (GAUDINE e THORNE, 2001; ETZIONI, 1988; REST, 1986). Como reforçam Gaudine e Thorne (2001, p. 176), "frequentemente, a decisão ética é emocionalmente carregada; porém isso não sugere, necessariamente, que o processo de decisão ética não seja racional".

Intuição, emoção e razão estão todas envolvidas no julgamento moral. Não de modo compartimentalizado, mas de modo interdependente e simultâneo. Apenas para efeito de exposição teórica, é possível afirmar que, por um lado, existem processos explícitos ou conscientes, aqueles ligados ao "raciocínio", de ordem propriamente intelectual, enquanto que, por outro lado, existem processos implícitos e subconscientes, aqueles de ordem propriamente intuitiva e afetiva, ambos atuando na deliberação moral realizada pelo indivíduo (SCHWARTZ, 2016; WOICESHYN, 2011). De acordo com Woiceshyn (2011, p. 319), "isso é consistente com o modelo de processamento dual que agora domina a ciência cognitiva e a literatura geral sobre tomada de decisão: ambos, razão consciente e processos subconscientes, intuitivos, operam quando decisões estão sendo tomadas".

Por certo, o fato de possuir uma dimensão intuitiva e afetiva não faz do julgamento moral algo irracional (LA TAILLE, 2006; GAUDINE e THORNE, 2001; ETZIONI, 1988). Da mesma forma, ao contrário do que entendeu Simon, os elementos intuitivos e afetivos do julgamento não implicam limitações da racionalidade, mas precisamente o contrário. Nesse sentido, é importante notar, como denunciaram Miller, Hickson e Wilson (2004), Reed (1998) e Guerreiro Ramos (1989), que o conceito de racionalidade se encontra tão arraigado ao cálculo utilitário de consequências "frio" na Administração e nos Estudos Organizacionais que talvez fosse mais produtivo substituí-lo pelo conceito de "inteligência", como fez Dewey, ao invés de tentar reformá-lo ou expandi-lo.

Segundo Edel e Flower (2008), em seus escritos Dewey e Tufts preferem a ideia de inteligência em substituição à ideia de razão e racionalidade, atribuindo à primeira mais do que a mera capacidade fria de raciocínio: "na inteligência existe um elemento sintético ou criativo, além daquele analítico, que vai além do senso estreito de raciocínio e inclui imaginação e sentimento" (EDEL e FLOWER, 2008, p. XXIV). Então, embora esteja associada com a razão e também dependa da consciência, a inteligência tem mais a ver com a capacidade humana de atribuir sentido às coisas e ações do que com a capacidade computacional comumente associada ao termo "racionalidade". Nas palavras do próprio Dewey (1950, p. 238), "a inteligência diz respeito à antecipação do futuro, de modo que a ação possa ter ordem e direção. Ela tem também a ver com os princípios e critérios de julgamento".

Seja como for, recolocar a moralidade como componente fundamental da racionalidade (ou da "inteligência") significa reconhecer o caráter propriamente humano e social da decisão, afastando a concepção mecanomórfica de agente decisor, como desejou Guerreiro Ramos (1989). Como diria esse autor, significa devolver ao conceito de racionalidade aquilo que lhe era mais próprio, a saber, sua substantividade.

\section{CONSIDERAÇÕES FINAIS}

A racionalidade limitada representa, sem sombra de dúvidas, um importante marco reflexivo quando o assunto é a decisão gerencial. A partir dela, Simon edificou uma teoria da decisão mais realista do que aquela oriunda do pensamento econômico neoclássico e, portanto, mais adequada para descrever como os agentes organizacionais avaliam e escolhem suas opções de ação.

Todavia, embora tenha se proposto a criticar a racionalidade plena, a racionalidade limitada de Simon não representa, propriamente, uma ruptura com o modelo anterior. Trata-se, sim, de um modelo mecanomórfico que assume que a racionalidade do agente decisor deve se aproximar o máximo possível da racionalidade plena, embora Simon reconheça que isso não seja possível na prática.

A racionalidade limitada de Simon ainda permanece circunscrita ao modelo neoclássico de racionalidade que ele se propôs a criticar. Figura como uma racionalidade que quer ser plena, mas que não pode, devido às limitações informacionais e computacionais do ser humano. É justamente para tentar mitigar essas limitações que existem, de acordo com Simon (1979), as teorias das organizações e a Ciência da Administração. Em uma interpretação mais livre, é possível dizer que Simon (1979, 1989) lamenta os limites da racionalidade perfeita e sonha com o dia em que os homens terão habilidades suficientes para poder chegar bem mais perto dela. "Logicamente, a racionalidade do tipo descrito pelo modelo comportamental [o modelo 
da racionalidade limitada] não é a ideal. Assim como também não garante que nossas decisões sejam coerentes" (SIMON, 1989, p. 34). A busca de Simon pela racionalidade plena é tão profunda que esse autor chega a propor que as organizações podem suplantar significativamente os limites da racionalidade individual para se tornarem, elas próprias, racionais.

Dentre as principais limitações do modelo teórico de Simon, encontradas neste estudo, a mais significativa é aquela que diz respeito ao fato da racionalidade limitada negligenciar o aspecto moral dos julgamentos e escolhas humanas. Na verdade, a moralidade não é o único aspecto relevante da decisão que Simon opta por negligenciar. Como complementa Reed (1998, p. 68), "é notável a exclusão de variáveis importantes como política, cultura, moral e história do modelo da 'racionalidade limitada'". Todavia, como sustentam Dewey $(1964,1950,2008$ a) e Etzioni (1988), além de outros autores, a moralidade é uma dimensão basilar e estruturante da racionalidade e das escolhas humanas.

Embora tenha reconhecido que as escolhas humanas estão baseadas em critérios morais anteriores ao cálculo utilitário de consequências, Simon opta por considerar tais critérios decisórios como irracionais, dicotomizando, assim, "racionalidade" e "moralidade", "fato" e "valor". A separação artificial que Simon impõem entre "fato" e "valor", sob o argumento de que proposições éticas não podem ser verificadas empiricamente, além de ser injustificável sob o ponto de vista da conduta cotidiana (PROVIS, 2010; DEWEY, 1950, 1964, 2008a, 2008b; PUTNAM, 2002; ETZIONI, 1988), pertence a uma perspectiva de ciência que, segundo Provis (2010) e Putnam (2002), encontra-se hoje sob forte questionamento. Além disso, complementa Lacey (2006, p. 254), nessa perspectiva questionável de ciência "a dicotomia entre fato e valor fica reforçada pela dicotomia entre objetivo e subjetivo". O que todos esses autores sustentam, cada qual ao seu modo, é que "fatos materiais" e "fatos morais" estão imbricados e constituem, para o agente decisor, dimensões sobrepostas da mesma realidade empírica. Além disso, esses autores sustentam que embora muitas vezes os fatos morais apresentem um viés imaterial, eles podem ser tão claramente percebidos por um "observador" quanto podem os fatos materiais. É justamente por negar essa "realidade moral" que a teoria da racionalidade limitada ainda está muito longe de ser útil ao estudo aprofundado e à intervenção concreta sobre o comportamento administrativo, a despeito dos seus avanços quando comparada ao modelo da racionalidade plena.

Uma teoria moral da racionalidade, mais ampla e compreensiva para efeito de investigação das decisões gerenciais, deve enxergar além da busca pelos meios mais eficientes para se chegar a determinado fim. Ela deve, segundo Etzioni (1988), ser capaz de explicar tanto as escolhas dos meios quanto a formação dos próprios fins esperados nas deliberações. Afinal, a moralidade está presente tanto na definição dos fins da ação quanto na escolha dos meios (DEWEY, 1964, 2008b).

Intuição, emoção, padrões morais de julgamento e razão são todos elementos necessários para a edificação de uma teoria moral da racionalidade que, baseada na valoração, seja efetivamente capaz de romper com a concepção ortodoxa da racionalidade plena.

Valorar é perceber, avaliar e atribuir "valor" (moral ou não) a algo. Para que haja valoração são necessários critérios de julgamento, o que Putman (2002) entende por "conceitos". A valoração moral é realizada por meio do emprego de padrões ou princípios éticos intersubjetivos, os "conceitos" éticos, que os agentes decisores utilizam racionalmente para identificar e avaliar o "peso" moral das diversas opções de conduta. Embora sejam obtidos culturalmente, esses padrões ou princípios caracterizam e modelam o "eu" de quem julga e decide, indicando suas preferências, tendências e perspectivas. Além disso, tais padrões pertencem a um contexto histórico e institucional específico que não pode ser ignorado, em nome de um critério "universal" de escolha - como é a "eficiência" na leitura de Simon (1979), caso se deseje compreender porque as pessoas dão importância desigual às coisas ao decidir.

Na prática, o emprego dos padrões morais nas decisões implica que as coisas somente precisam ser "calculadas" quantitativamente após terem sido consideradas "boas" ou "ruins" qualitativamente. Isso significa dizer que um comportamento somente pode ser "racional", tal como entende Simon, dentro de uma perspectiva moral preexistente para o agente decisor, como também admitiu o próprio Simon $(1979,1989)$. Isso não significa, todavia, que o cálculo utilitário de consequências seja irrelevante em se tratando do julgamento e da tomada de decisão. Significa apenas que ele não acontece fora de um contexto moral que lhe dá significado. Assim, negar a importância do cálculo utilitário de consequências na racionalidade seria tão equivocado quanto negar sua dimensão moral.

Para que seja possível compreender como as decisões mais complexas são tomadas, faz-se necessário descobrir qual é ou quais são os padrões éticos que os indivíduos racionalmente usam para julgar as alternativas de ação e fazer suas escolhas, 
já que além de indissociável e inalienável, a moralidade é uma dimensão basilar da conduta humana. Nenhuma teoria da decisão, que se pretenda efetiva, pode se abster de considerar essa dimensão basilar, sob pena de não abordar os aspectos propriamente humanos e sociais da racionalidade.

A fim de superar a mera descrição das decisões humanas e avançar na compreensão de como julgam e decidem os agentes organizacionais, é preciso começar admitindo que os padrões ou princípios morais ocupam um papel essencial junto com a razão. Além disso, é necessário também reconhecer que nossa moralidade e seus respectivos padrões ou princípios éticos de julgamento são parte de nossa cultura (ETZIONI, 1988; BIRD e WATERS, 1987; COLTRO e SANTOS, 1998). E a cultura, por sua vez, representada por nossos hábitos, costumes e instituições, antes de ser um limitador ou bloqueador da racionalidade, é, em verdade, o comburente da ação reflexiva, inteligente e racional (DEWEY e TUFTS, 2008; DEWEY, 2008a; BERGER e LUCKMANN, 1985).

De modo complementar, é importante enfatizar, também, que os padrões ou princípios morais de julgamento não necessariamente equivalem a esquemas heurísticos simplificadores da realidade decisória. A teoria da racionalidade limitada sugere que quanto maior for a incerteza vivenciada pelo agente decisor, mais importantes serão as heurísticas e a intuição no processo decisório que se pretende efetivo. Todavia, este artigo propõe, com base na discussão das ideias de Dewey sobre valoração, deliberação e padrões morais, que situações de incerteza, especialmente vivenciadas em decisões não rotineiras e complexas que envolvem desdobramentos morais incertos, podem fazer com que o agente decisor se veja obrigado a ponderar variáveis inicialmente não observadas na avaliação das opções de conduta, levando-o, então, a buscar mais informações sobre o problema decisório em questão e, por conseguinte, retirando-lhe a possibilidade de "acomodação". Afinal, para Dewey (1950, p. 216), "a deliberação é um trabalho de descoberta". Como sugere o próprio Dewey (1964), é, acima de tudo, um trabalho de autodescoberta. Isso porque o julgamento moral das opções de conduta pode ser tão "perturbador" para o agente decisor quanto mais evidentes se tornarem os conflitos ou dilemas envolvidos nessas opções. Suas escolhas podem inclusive induzi-lo a uma reflexão não desejada sobre seu próprio "eu", mais especificamente, sobre seu próprio caráter. Podem fazê-lo confrontar suas preferências, perspectivas e tendências até então obscuras de conduta, revelando, para ele próprio, o que realmente lhe importa ao escolher determinado curso de ação.

Por isso, antes de ser precipitadamente entendidos como critérios "irracionais", que limitam ou distorcem o processo decisório, os padrões morais devem ser entendidos como critérios que habilitam e estimulam a racionalidade. Afinal, como já havia observado Weber $(2000,2002)$, o conceito de racionalidade não se restringe ao cálculo extensivo de utilidades e consequências das ações, mas também se dá a partir de outras lógicas. Em suas palavras, "algo nunca é irracional por si mesmo, mas sim [por meio] de uma perspectiva racional [algo se torna irracional]. Para o incrédulo, todo modo de vida religioso é irracional; para o hedonista [o é] qualquer padrão ascético" (WEBER, 2002, p. 140).

Por fim, vale notar que se o reconhecimento dos "limites da racionalidade plena" trouxe maior aproximação da teoria da decisão junto ao mundo prático da decisão, a incorporação da moralidade à racionalidade significa uma aproximação ainda maior. Em síntese, os avanços ou as vantagens que essa "nova" teoria moral da racionalidade pode trazer para o estudo das decisões gerenciais são as seguintes: 1) ela permite compreender como os gestores avaliam e escolhem os fins para os quais sua ação é orientada, ao invés de tomá-los como preexistentes, autoevidentes e moralmente indiferentes, e ao invés de limitar-se à simples descrição da seleção dos meios de ação com base no critério "universal" da eficiência; 2) ela permite apreender os critérios intersubjetivos, normativos e afetivos que orientam as decisões humanas racionais, mais especificamente, os padrões morais de valoração; 3) justamente por possibilitar a apreensão dos padrões morais de valoração, ela reconhece a importância da cultura, das instituições e da história no processo de tomada de decisão; 4) ela entende a deliberação humana tanto como uma manifestação do "eu" que decide quanto como uma manifestação da "sociedade" por meio do "eu" que decide, revelando a tensão que existe entre o indivíduo e a comunidade sem, entretanto, privilegiar nem um nem outro; 5) ela contempla os conflitos e dilemas típicos das decisões humanas complexas, inclusive aqueles criados pela tensão que o emprego simultâneo de critérios morais diferentes de valoração pode trazer ao agente decisor; 6) ela integra, em um quadro teórico e epistemológico coerente, "razão" e "emoção", "ética" e "fato", "subjetividade" e "objetividade", de um modo abrangente e compreensivo para o estudo da decisão nas organizações; e, finalmente, 7) ela efetivamente rompe com a concepção da racionalidade plena, o que Simon não fez ao propor a teoria da racionalidade limitada.

A título de limitação e sugestão para pesquisas futuras, mostra-se oportuno reconhecer que este artigo abordou os padrões morais de valoração e decisão gerencial apenas de modo teórico e abstrato. Respostas sobre quais são eles ou qual é seu conteúdo específico são necessárias e podem ser obtidas por meio de pesquisas empíricas, conduzidas diretamente junto aos gestores, como aquela pioneira, descrita por Bird e Waters (1987). 


\section{REFERÊNCIAS}

BALESTRIN, A. Uma análise da contribuição de Herbert Simon para as teorias organizacionais. Revista Eletrônica de Administração, v. 8, n. 4, p. 1-17, 2002.

BARNARD, C. As funções do executivo. São Paulo: Atlas, 1979.

BERGER, P.; LUCKMANN, T. A construção social da realidade. Petrópolis, RJ: Vozes, 1985.

BIRD, F.; WATERS, J. The nature of managerial moral standards. Journal of Business Ethics, v. 6, n. 1, p. 1-13, 1987.

CARVALHO, A.; VIEIRA, M. (Org.). Organizações, cultura e desenvolvimento local: a agenda de pesquisa do Observatório da Realidade Organizacional. Recife: Ed. Ufepe, 2003.

CERTO, S.; PETER, J. Administração estratégica: planejamento e implantação da estratégia. São Paulo: Makron Books, 1993.

CHANLAT, J. F. Ciências sociais e management. São Paulo: Atlas, 1999.

COLTRO, A.; SANTOS, S. A. A busca da compreensão da racionalidade e da ética da ação administrativa na gestão de uma organização hospitalar pública. In: ENCONTRO NACIONAL DE PÓS-GRADUAÇÃO EM ADMINISTRAÇÃO, 22., 1998, Foz do Iguaçu. Anais... Foz do Iguaçu, PR: AnPAD, 1998.

DEWEY, J.; TUFTS, J. Ethics. Carbondale: Southern Illinois University, 2008.

DEWEY, J. Human nature and conduct: an introduction to social psychology. Nova York: Random House, 1950.

DEWEY, J. Teoria da vida moral. São Paulo: Ibrasa, 1964.

DEWEY, J. The function of propositions of quantity in judgment. In: DEWEY, J. Logic: the theory of inquiry. Carbondale: Southern Illinois University, 2008a. p. 200-219.

DEWEY, J. Theory of valuation. Carbondale: Southern Illinois University Press, 2008b.

EDEL, A.; FLOWER, E. Introduction. In: DEWEY, J.; TUFTS, J. Ethics. Carbondale: Southern Illinois University, 2008.

ELM, D.; RADIN, T. Ethical decision making: special or no different? Journal of Business Ethics, v. 107, p. 313-329, 2012.

ETZIONI, A. The moral dimension: toward a new economics. Nova York: The Free, 1988.

GAUDINE, A.; THORNE, L. Emotion and ethical decision-making in organizations. Journal of Business Ethics, v. 31, p. 175-187, 2001.

GUERREIRO RAMOS, A. A nova ciência das organizações: uma reconceituação da riqueza das nações. 2. ed. Rio de Janeiro: Ed. FGV, 1989.

HAYIBOR, S.; WASIELESKI, D. Effects of the use of the availability heuristics on ethical decision-making in organizations. Journal of Business Ethics, v. 84, n. 1, p. 151-165, 2009.
LACEY, H. Relação entre fato e valor. Cadernos de Ciências Humanas: Especiarias, v. 9, n. 16, p. 251-266, 2006.

LA TAILLE, Y. Moral e ética: dimensões intelectuais e afetivas. Porto Alegre: Artmed, 2006

LUPPE, M.; ANGELO, C. As decisões de consumo e a heurística da ancoragem: uma análise da racionalidade do processo de escolha. Revista de Administração Mackenzie, v. 11, n. 6, p. 81-106, 2010. Edição especial.

MILLER, S.; HICKSON, D.; WILSON, D. A tomada de decisão nas organizações. In: CLEGG, S.; HARDY, C.; NORD, W. (Org.). Handbook de estudos organizacionais. São Paulo: Atlas, 2004. v. 3, p. 282-310.

MOTTA, F. C. P.; VASCONCELOS, I. Teoria geral da administração. São Paulo: Pioneira Thomson Learning, 2004

PROCÓPIO, M. Ética e fato na ciência administrativa: em busca de uma alternativa epistemológica. Revista da Faculdade de Administração e Economia, v. 3, n. 2, p. 2-31, 2012.

PROVIS, C. Virtuous decision making for business ethics. Journal of Business Ethics, v. 91, p. 3-16, 2010.

PUTNAM, $\mathrm{H}$. The collapse of the fact/value dichotomy and other essays. Cambridge/London: Harvard University Press, 2002.

PUTNAM, R. Pragmatismo: a filosofia moral dos filósofos pragmáticos. In: CANTO-SPERBER, M. (Org.). Dicionário de ética e filosofia moral. São Leopoldo, RS: Ed. Unisinos, 2003. v. 1, p. 372-379.

REED, M. Teorização organizacional: um campo historicamente contestado. In: CLEGG, S.; HARDY, C.; NORD, W. (Org.). Handbook de estudos organizacionais. São Paulo: Atlas, 1998. v. 1, p. 61-98.

REST, J. Moral development: advances in research and theory. Nova York: Praeger, 1986.

SCHOEMAKER, P. Strategic decisions in organizations: rational and behavioral views. Journal of Management Studies, v. 30, n. 1, p. 107-129, 1993.

SCHWARTZ, M. Ethical decision-making theory: an integrated approach. Journal of Business Ethics, v. 139, p. 755-776, 2016.

SIMON, H. A. Comportamento administrativo. 3. ed. Rio de Janeiro: Ed. FGV, 1979

SIMON, H. A. A razão nas coisas humanas. Lisboa: Gradiva, 1989.

WEBER, M. Economia e sociedade. 3. ed. Brasília, DF: Ed. UnB, 2000. v. 1

WEBER, M. A ética protestante e o espírito do capitalismo. São Paulo: Martin Claret, 2002.

WOICESHYN, J. A model for ethical decision making in business: reasoning, intuition and rational moral principles. Journal of Business Ethics, v. 104, p. 311-323, 2011.

Marcos Luís Procópio

Doutor e Mestre em Administração pela Universidade Federal de Lavras (UFLA); Bacharel em Administração pela Pontifícia Universidade Católica de Campinas (PUCCAMP); Professor Adjunto da Universidade do Estado de Mato Grosso (UNEMAT), Sinop - MT, Brasil. E-mail: marcos@unemat-net.br; prof.marcosprocopio@gmail.com 